\title{
Flensborg og oksehandelen i årtierne op til 1500
}

\section{af Poul Enemark}

Fra en beskeden start omkring år 1400 nåede den danske okseeksport o. 1500 anselige dimensioner. Flensborgs oksehandlere omsatte på dette tidspunkt imponerende beløb. Afhandlingen her belyser, hvordan oksehandelen udviklede sig i løbet af 1400-årene, og hvordan den gradvist blev omlagt fra efterårs- til forårseksport. Detaljeret berettes om de enkelte oksehandlere i Flensborg. Det påvises, at oksehandelen frem mod år 1500 medførte en klar social og økonomisk opstigning for erhvervets udøvere. I de første år træffer vi mest jævne prangere, til slut ansete købmænd. Det var rige folk, som ikke blot eksporterede okser, men også indførte fornemme og profitable klædevarer fra udlandet.

Universitetslektor, dr.phil. Poul Enemark har tidligere publiceret adskillige arbejder om emnet, og han er en af vore fineste kendere af denne tids handelshistorie. Denne artikel vil blive fortsat $\mathrm{i}$ næste årgang af Sønderjyske Årbøger, hvor tidsrummet ca. $1500-1520$ vil blive omtalt.

\section{Fra kornbrug til okseeksport}

Okserne var Danmarks hovedeksportartikel i 1500- og 1600-tallet. Staldfodringen og afsætningen gav store indkomster til adel og krone, og drivningen og omsætningen af dyrene i udlandet gav penge til danske købstadborgere. Men handelen med okser var af ældre dato. Spredte spor fører os tilbage i begyndelsen af 1400-tallet. Baggrunden for den stigende betydning må vel søges $i$ omlægninger $\mathrm{i}$ bedriftsstrukturen $\mathrm{i}$ landbruget og i ændringer $\mathrm{i}$ kostvanerne, der indtrådte i store dele af Vest-, Central- og Nordeuropa i løbet af senmiddelalderen.

Den såkaldte »senmiddelalderlige agrarkrise« ramte i Vesteuropa fortrinsvis det arbejdskrævende kornbrug. Befolkningsstagnation - eller ligefrem tilbagegang - som følge af de hyppige pestepidemier og mere generelt som resultat af en afvandring fra landbruget til byerne efterlod ødegårde, mangel på arbejdskraft og relativt stigende lønomkostninger til de betrængte kornproducenter. Da kornpriserne nærmest var vigende - $\mathrm{i}$ alt fald slet ikke holdt trit med prisudviklingen for så at sige alle andre varer - blev kornproduktionen i mange egne i Vesteuropa mindre rentabel. Samtidig blev stadig større kornmængder tilført fra Østeuropa, hvor vækstbetingelser og produktionsomkostninger artede sig fordelagtigere. 
Denne vedvarende uheldige økonomiske udvikling for kornbruget i Vesteuropa måtte på længere sigt flere steder drage omlægninger af bedriften efter sig. I nogle egne spores omlægninger til nye afgrøder, andre steder afløstes det intensive kornbrug af ekstensivt fårehold med uldproduktion eller kvæghold med kødproduktion, der fordrede mindre arbejdskraft. De store flokke af sommergræssede dyr kunne passes af et par hyrder på enge, overdrev eller ødejorder, der henlå med græs eller var sprunget i busk. Problemet ved denne driftsform var mangelen på vinterfoder. Et stort antal dyr måtte slagtes $\mathrm{i}$ november måned, før en beskeden bestand af okser blev sat på stald til overvintring med henblik på næste sommers græsning. ${ }^{1}$

Det store overskud af sommergræssede okser kunne enten slagtes på gårdene eller drives til efterårsmarkeder, hvor byernes slagtere gjorde opkøb side om side med opkøbere fra hofholdninger og gejstlige institutioner, der selv foretog slagtning og nedsaltning til det store vinterforråd. En væsentlig del af dette okseopkøb om efteråret behøvede derfor ikke at være i hænderne på en egentlig købmandsstand, men var hyppigt overladt en blandet gruppe af prangere og slagtere, der senere foretog slagtning, partering, udskæring og saltning af kodet.

Bedriftsomlægningerne $i$ landbruget forløb side om side med gradvis ændring af kostvanerne fra ensidig stivelsesholdig kornernæring til mere proteinrig kost med et langt større kødforbrug - $\mathrm{i} ø v$ rigt også større, end vi kender det $\mathrm{i}$ dag. Det store udbud af kød og andre slagtningsprodukter befordrede

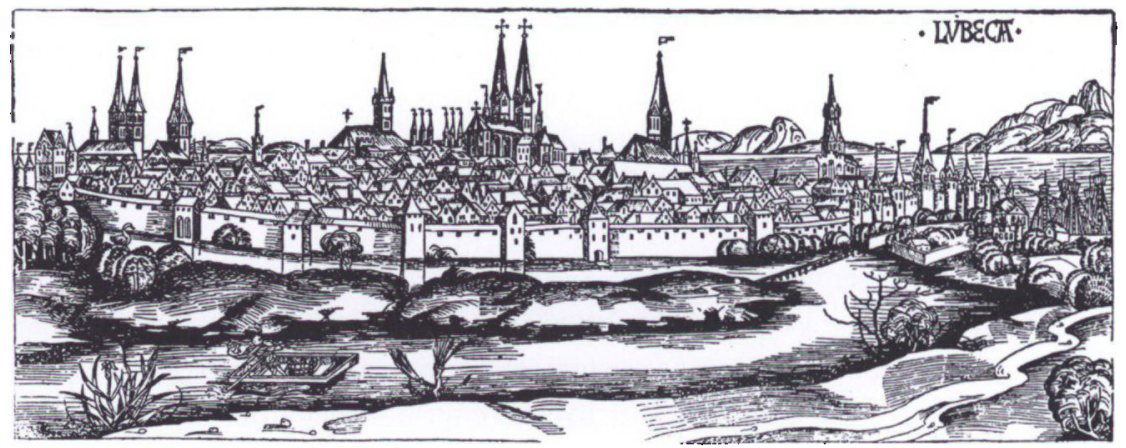

Lybak, der var hovedaftager af de danske okser fra efterdrsmarkederne i Ribe og Kolding, havde $i$ slutningen af 1400-tallet 20-25.000 indbyggere og var ubetinget Ostersøomrddets storste by. Pd dette trasnit fra Hartman Schedels Weltchronik (Nürnberg 1493) ses byen fra est med floden Wakenitz $i$ forgrunden. Til venstre ses domkirken, i midten Mariekirke og rddhusets 6 slanke spir, der markerer torvets beliggenhed. Til højre ses Burgtor med vejforbindelse mod Mecklenburg. Mod vest la Holstentor ud til Travefloden og vejen via Plön, Kiel og Gottorp til Flensborg. Her gengivet efter Bjorn Poulsen: Land-By-Marked, 1988 s. 164. 
naturligvis de ændrede signaler i ernæringen. Et tilbehør ved slagtningerne var det enorme lager af okse- og kohuder, der blev råvarer for skomagere, sudere, skindere, garvere, remsnidere med flere håndværk, der netop i 1400-tallet vandt en utrolig udbredelse og dannede store og magtfulde håndværkslav ligesom de såkaldte »knockenhauere«, betegnelsen for slagterne. Et vidnesbyrd om de nye tider var "knockenhauer"-opstanden i Lybæk 1380-84, hvor de nye, betydningsfulde håndværksgrupper søgte at skaffe sig indflydelse $\mathrm{i}$ bystyret. ${ }^{2}$

I de spredte efterretninger om dansk udskibning i 1300-tallet møder man jævnligt konserverede og emballerede slagtningsprodukter og fedevarer fra kvægbruget som vidnesbyrd om, at senmiddelalderens strukturændringer og nye ernæringsbehov tidligt stillede krav til danske leverancer. Denne udskibning holdt sig særdeles intenst hele 1400-tallet igennem især fra den sjællandske øgruppe og de østdanske landskaber, mens Jylland og Fyn i højere grad prægedes af transportruterne med levende okser. ${ }^{3}$

I striden mellem Erik af Pommern og de holstenske grever klagede disse over, at kongen var begyndt at opkræve told af forbipasserende okser ved sin borg Niehuus nord for Flensborg, hvilket må tages som vidnesbyrd om, at oksetransporterne allerede da havde et så kontinuerligt præg, at de var et iøjnefaldende toldobjekt. ${ }^{4}$

Da hertug Adolf af Slesvig i 1455 stadfæstede Haderslevborgeres ret til at købe og sælge varer toldfrit i deres egen by, tilføjes dog, at om de købte okser "på driften « eller i Nørrejylland, skulle de betale told deraf som andre handlende. ${ }^{5}$ Her træder den østjyske driverrute forbi Haderslev klart frem som en etableret realitet. I 1448, 1452, 1454 og 1459 hører man om stridigheder som følge af lybske knockenhaueres drivning af danske okser uden om Kiel og Plön, altså ad ruten Gottorp-Kiel-Preetz-Plön til Lybæk. I 1449 måtte hertug Adolf ligefrem henstille til byrådet i Lybak, at man ikke udstrakte borgernes opkøb af levnedsmidler $\mathrm{i}$ hertugdømmerne alt for vidt. I Kiel klagede man over, at lybske kvægopkøb skabte dyrtid for Kiels egne borgere. ${ }^{6}$

Men de hanseatiske okseopkøbere fra Lybæk, Hamborg og Lüneburg drog endnu længere nordpå. I 1465 har vi efterretning om et lybsk okseopkøb fra en Randersborger foretaget i Ribe, efter al sandsynlighed på Ribermarked, det siden så ansete oksemarked.' I 1489 ansøgte Lüneburg kong Hans om sikkerhed for byens borgere, der plejede at besøge Ribermarked for at købe okser. Tilsvarende anmodninger fra 1492-93, 1481-83 og 1475 gælder sandsynligvis også oksekøbet i Ribe, selv om det ikke nævnes udtrykkeligt. ${ }^{8}$

Der er grund til at antage, at et efterårsmarked for okseopkøb også kan føres tilbage til samme tid i Kolding, så da en handelsforordning i 1475 forbyder, at danske må drive deres okser længere syd på end til Ribe, Kolding og Assens, hvor dyrene skulle afsættes til udenlandske opkøbere, må man gå 
ud fra, at forordningsbestemmelsen blot afspejler indarbejdet praksis, og ved at indskærpe markedspligten sikrer kronen sig, at toldafgiften kommer ind. ${ }^{9}$

\section{Toldregnskaberne og udviklingen 1485-1519}

Fyldige toldregnskaber er bevaret til belysning af såvel markedsomsætningen i Ribe og Kolding som oksedrivningen sydpå i årtierne omkring 1500. Toldopkrævningen på efterårsmarkederne i Ribe Vor Frue dag (8/9) og i Kolding St. Franciscidag (4/10) foreligger så at sige år for år i det forste årti af 1500-tallet aflagt til dronning Christines regnskabsfører. Enkelte år efter 1505 findes også oppebørsel af told om foråret $\mathrm{i}$ dagene omkring Marie bebudelsesdag (25/3) $i$ begge byer. Et egentligt forårsmarked ved denne tid skabtes i alt fald i Ribe, og drivningen på dette tidspunkt blev tillige almindelig i Kolding, hvilket fremgår af oppebørselsregnskaber for dronningen (der efter Hans' død 1513 havde beholdt indkomsterne af disse byer) $\mathrm{i}$ årene $1519-21 .^{10}$

Det ældste danske årsregnskab over toldindtægter er bevaret fra Gottorp (2/12 1484 - 1/12 1485). ${ }^{11}$ Det efterfølges af årsregnskaber fra 1491 (20/2 1491 - 19/2 1492), 1498, 1501, 1508, 1510-11 og 1519, hvortil slutter sig det sidste halve år af $1497(28 / 7-31 / 12) .{ }^{12}$ De enkelte toldposter er ført på den handlendes navn og antal okser (eller emballager af andre varer) i såvel markedsregnskaber som årsregnskaber, de sidste delt op dag for dag med præcis datoangivelse. Både markedsregnskaberne og årsregnskaberne fra 1485 og 1491 er i almindelighed forsynet med lokalitetsangivelse for de handlende, hvilket letter fordelingen af handelen på de enkelte byer. Det gælder dog ikke konsekvent, og det galder slet ikke de efterfølgende årsregnskaber fra Gottorp, hvilket unægtelig gør en lokalisering af de handlende i disse år noget mere besværlig. Da der kan iagttages stor kontinuitet $\mathrm{i}$ oksehandelen, vil identifikation af hovedparten af de handlende og deres oksekontingenter dog være mulig. Identifikationen kan i øvrigt støttes af andre samtidige kildeudsagn. ${ }^{13}$

I Gottorpregnskabet 1485 fortoldes i alt ca. 13.000 okser og i 1491 ca. 18.200; men årsfordelingen koncentrerer sig omkring ganske bestemte årstider:

Skema 1:

1485 :

1491:

$\begin{array}{rrcr}23 / 3-16 / 4: & 2.494 \text { okser } & 19 / 3-7 / 4: & 6.648 \text { okser } \\ 8 / 6-30 / 8: & 194 \text { okser } & 17 / 5-7 / 9: & 365 \text { okser } \\ 11 / 9-30 / 9: & 3.567 \text { okser } & 10 / 9-29 / 9: & 5.144 \text { okser } \\ 2 / 10-30 / 10: & 6.760 \text { okser } & 1 / 10-30 / 10: & 5.455 \text { okser } \\ 7 / 11-24 / 11: & 6 \text { okser } & 1 / 11-12 / 2: & \frac{606 \text { okser }}{18.218 \text { okser }}\end{array}$


Der kan ikke herske tvivl om, at septembereksporten, der hober sig op mellem 12. og 17. september, altså ugen efter Ribermarked $8 / 9$ med en passende drivertid, afspejler omsætningen på dette marked. ${ }^{14}$ Knap så klart kan oktobereksporten uden videre identificeres med Koldingmarkedet, som i 1485 ganske vist fandt sted på Mikkelsdag (29/9) og først i 1491 af kongen flyttedes til St. Francisci dag $(4 / 10) .{ }^{15}$ Den tætte koncentration i 1485 om dagene 4.-8. oktober og i 1491 om 8.-13. oktober må dog givetvis afsløre Koldingmarkedet, medens adskillige fynboer $i$ sidste halvdel af oktober røber færgefarten over Assens med kontingenterne fra Fyn.

Forårsdrivningen, som markerede sig i dronningens regnskaber fra Ribe og Kolding ca. 25/3 i årene fra 1505 og fremefter, er af meget ældre dato, viser Gottorpregnskaberne. Forårsdrivningen i 1485 med over 2.000 okser i dagene fra 27. marts - 5. april og 1491 med over 6.000 okser i dagene mellem 29.marts og 5.april viser med al ønskelig tydelighed, at passagerne harmonerer med drivningstidspunkterne $\mathrm{i}$ de to jyske byer, så der er grund til at antage, at forårsdrivningen var aktuel i Jylland allerede i slutningen af 1480'erne; og den var åbenbart i stærk vækst. Denne vækst fortsatte i de følgende 30-40 år, hvilket Gottorpregnskaberne klart dokumenterer:

Skema 2:

$\begin{array}{lrrrrrrrr} & 1485 & 1491 & 1498 & 1501 & 1508 & 1510 & 1511 & 1519 \\ \text { Årsmængde } & 13.000 & 18.200 & 18.700 & 28.300 & 26.000 & 14.100 & 18.900 & 29.200 \\ \text { Marts/apr. } & 2.500 & 6.600 & 6.200 & 9.600 & 9.500 & 8.700 & 7.700 & 20.900 \\ \text { Sept./okt. } & 10.300 & 10.400 & 11.800 & 17.800 & 15.700 & 4.300 & 9.500 & 7.500 \\ \text { Forår i \% } & 19 & 37 & 33 & 34 & 37 & 62 & 41 & 72 \\ \text { Efterår i \% } & 79 & 58 & 63 & 63 & 61 & 31 & 51 & 26\end{array}$

Antallet er afrundet $i$ hele 100 stk.

1510-11 er præget af krigen mellem Danmark og Lybæk 1509-12. Krigen medførte, at eksporten fra Danmark en tid ligefrem var spærret og i 1511 kun var tilladt ved licenstildeling med forpligelse til at føre okserne over Elben vestpå, så de ikke kom Lybæk til gode. De øvrige år viser en klar udviklingslinie. Den samlede eksportmængde stiger til mere end det dobbelte, men forårseksporten 8-dobles i perioden og er i 1519 totalt dominerende. Efterårseksporten steg dog frem til århundredskiftet, men ramtes hårdt under krigen med Lybæk, hvorefter den tilsyneladende aldrig rigtig kom i gang igen. Eksporten uden for drivertiderne beløb sig kun til et par procent $\mathrm{i}$ de normale år. ${ }^{16}$

Forårseksporten var et brud med senmiddelalderens slagtekvæghold baseret på sommergræsning og efterårsslagtning med minimering af vinterfoderet. Det var $\mathrm{i}$ virkeligheden den ny tid med staldfodring, der tog sin begyndelse. Nogen 


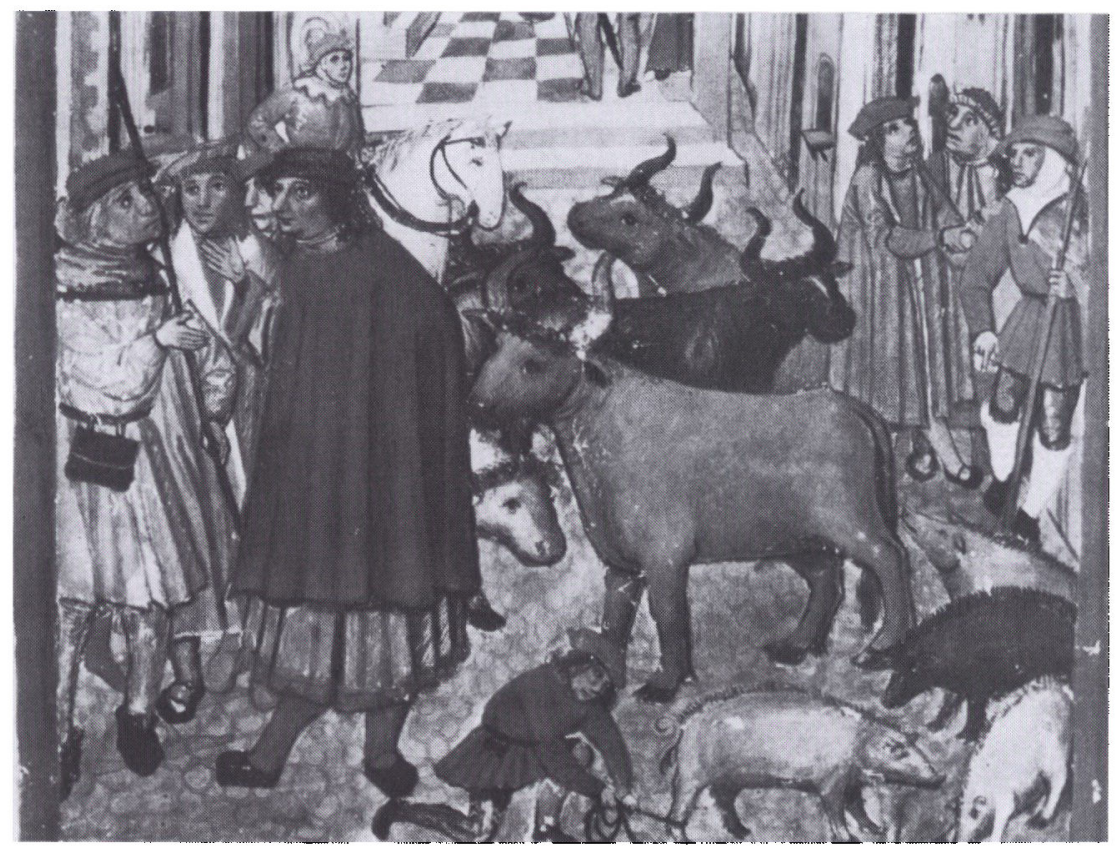

Oksemarked i Hamborg ca. 1490. Illustration fra et händskrift af en hamborgsk Stadtrecht 1497. Hamborgs oksemarked faldt i dagene omkring den hellige biskop Felicianus' dag (20. oktober), og de omsatte okser pả billedet kunne meget vel tankes at vare opkøbt pd̊ danske efterårsmarkeder $i$ Ribe (8/9) eller $i$ Kolding (4/10). Der var fin tid til drivningen. Bemark $i$ ovrigt, hvor smd dyrene var. Staatsarchiv Hamburg.

egentlig staldfedning skal man næppe regne med; men dyrene måtte være i en fodringsstand, så de kunne klare den lange vandring til Elben og siden vestover. Opkøberne var vesttyske og hollandske prangere eller marskbønder, der lod dyrene gå til fedning en sommer i marskegnene langs Elben, Weser, $\mathrm{i}$ Oldenburg, Ost- og Vestfrisland, inden de bragtes til afsætning i Vesteuropas storbyer Køln, Antwerpen og Amsterdam som topfedet kvæg antagelig til toppriser. $^{17}$

Danmark var ved at blive leverandør af halvfabrikat: magre øksne til opfedning og senere levering i Vesteuropas kødkonsumcentre. Baggrunden for denne produktionsskala træder os i møde i et markedsregulativ fra Køln kvægmarked i 1492, der advarer opkøberne mod at forveksle danske, ungarske og polske okser, der "er taget direkte fra ploven" med gode fedede frisiske okser, der var hentet fra marskgræsgangene. ${ }^{18}$

De sommergræssede danske efterårsokser var simpelthen for ringe til forventningerne blandt Vesteuropas kødkonsumenter, der var godt vante; og 
udslidte og afmagrede efter den lange vandring har efterårsokserne sikkert ikke kunnet indbringe deres pris. Men forårsokserne har kunnet betales bedre i forventning om marskfedningens kvalitetsforbedring.

Der er grund til at antage, at forårsdrivningen af okser var af ret ny dato i 1485. Den må formentlig have været et ukendt fæenomen, da man lovgav i 1475. Selv om prangere fra Zwolle, Kampen, Deventer, Nijmegen, Utrecht, Hasselt og Osnabrück fortoldede forårsokser i Gottorp, som de antagelig havde hentet i Danmark, så blev dog adskillige forårsokser drevet og fortoldet af danskere fra Ribe, Varde og Odense, hvilket jo faktisk var i strid med forordningsbestemmelsen i 1475. Men hvad med flensborgerne og hertugdømmets øvrige købmænd, som handelsforordningen fra 1475 overhovedet ikke omtaler?

\section{Flensborgernes oksehandel i 1485}

De to ældste Gottorpregnskaber bekræfter fuldt ud, hvad det øvrige kildemateriale gav spredte oplysninger om: de tyske okseopkøb fra Lybæk, Hamborg og Lüneburg på de danske efterårsmarkeder. I 1485 fortoldede tyskerne ca. 5.000 dyr eller knap 40\% og 1491 henved 50\%, 8-9.000 okser, fortrinsvis hentet på Ribe og Kolding efterårsmarkeder, hvilket tolddatoerne røber. Et noget mindre antal, omkr. 4.000 okser fortoldedes af handlende fra hertugdømmerne Slesvig og Holsten, og hér indtog Flensborg en helt dominerende position. ${ }^{19}$ I 1485 fortoldede 25 flensborgere 2.670 okser, ca. $20 \%$ af regnskabets okser. Arsfordelingen er iøjnefaldende:

Skema 3:

Forårsdrivning: $\quad 724$ okser ( $29 \%$ af saml. forårsdrivn.)

Sommerdrivning: $\quad 150$ okser ( $75 \%$ af saml. sommerdrivn.)

Septemberdrivning: 256 okser ( $7 \%$ af saml. septemberdrivn.)

Oktoberdrivning: $\quad 1.540$ okser ( $26 \%$ af saml. oktoberdrivn.)

Det fremgår altså tydeligt, at flensborgske borgere fortrinsvis gjorde deres efterårsopkøb på Kolding marked eller på »driften fra Nørrejylland « ad den østjyske drivervej $\mathrm{i}$ oktober måned, medens opkøb fra Ribe marked åbenbart var af underordnet betydning. Derimod viser den store procentandel, at flensborgerne tidligt engagerede sig $i$ forårsdrivningen. Talmæssigt betød sommeropkøbet ikke så meget, men netop flensborgere foretog jævnligt denne type lokale småopkøb uden for de egentlige drivningstider.

Jeppe Teglgård var Flensborgs største oksehandler i 1485. Om foråret drev 
han 255 okser i eget navn og 100 i forening med Merten Risenberg. Om sommeren kom han på ny med 54 okser og i oktober med 143, alt i alt ca. 500 okser for hans andel. Med 123 heste er han tillige registreret som årets største hestehandler. En omsætning af så enormt format må være oparbejdet gennem en årrække. Når Jeppe Teglgård ikke er registreret i 1491, skønt han og hustruen i 1494 har skænket memoriepenge ${ }^{19 a}$ til Mariekirken i byen, må det skyldes alder og svigtende helbred. Han må være død kort tid efter, men hustruen Bodil Teglgård omtales endnu 1509. Hvis den Nisse Teglgård, der 1490 blev medlem af Vor Frue købmandsgilde, var ægteparrets søn, som jo næppe kan være født senere end 1470, snarere lidt før, må Bodil Teglgårds fødselsdag antagelig have ligget noget før $1450 .{ }^{20}$ Jeppe Teglgård, der åbenbart var en del ældre end hustruen, kan følgelig meget vel have været over 50 år $\mathrm{i}$ 1485 , hvilket hans handels omfang tyder på.

Det er imidlertid påfaldende, at den anselige okse- og hestehandler ikke således som sønnen var medlem af byens købmandsgilde, men blot af det ydmyge Hellig Legemsgilde, lidt nedladende kaldt "skolelavet«, hvor han endda først blev optaget i 1477. Når hustruen Bodil i 1495 på en præsts anbefaling blev optaget som medlem i det fornemme Kalentegilde eller Hellig Trefoldighedsgildet, der rekrutteredes fra byens førende slægter, må det opfattes som en forsinket anerkendelse til manden, der må være død, siden han ikke omtales. ${ }^{2 !}$

Jeppe Teglgård har oprindelig ikke tilhørt byens ansete købmandskredse. Navnet Teglgård eller den plattyske form Tegelgarde, der normalt forekommer, peger mod en herkomst fra landbomiljø. Imidlertid er stednavnet såre almindeligt, så en geografisk placering bliver usikker. Da Teglgård i Bredsted sogn ved vestkysten er en beboelseslokalitet - ikke blot et stednavn - er det måske ikke noget urimeligt gat. ${ }^{22}$ Det ville tillige vare et sandsynligt geografisk udgangspunkt for en prangerkarriere, der må antages at have været Jeppe Teglgårds erhvervsstart.

Flensborgs anden store oksehandler i 1485 var Mathias Madsen, der om foråret fortoldede 105 okser sammen med Karsten Lund, som også var hans kompagnon om 83 okser 17/9, som muligvis kan være hentet på Ribe marked. Selv fortoldede Mathias 3 uger senere ikke mindre end 253 okser (8/10), som antagelig må hidrøre fra Kolding marked, og et mindre opkøb på 34 okser foretog han lokalt $\mathrm{i}$ august. I alt fortoldede han altså knap 300 okser selv og knap 200 med Karsten Lund, men i modsætning til Jeppe Teglgård tegnede han sig overvejende for efterårseksport af sommergræssede dyr. Han må antagelig være identisk med den "Masse Massen«, der blev medlem af Vor Frue købmandsgilde 1483, og han hørte næppe til byens mest ansete borgerskab, siden man ellers intet hører om ham. Han må være optaget i købmands- 
gildet $\mathrm{i}$ en meget fremskreden alder. Måske gælder det samme kompagnonen Karsten Lund, der først i 1484 blev medlem af såvel købmandsgildet som Hellig Legemsgildet. ${ }^{23} \mathrm{Han}$ var tillige en betydelig hestehandler. De var antagelig begge oprindelig prangere, ingen af dem træffes $\mathrm{i}$ regnskabet 1491, og $\mathrm{i}$ byens kildemateriale har de ikke sat sig yderligere spor.

Merten Risenberg, der om foråret drev 100 okser med Jeppe Teglgård, drev 11.oktober 165 okser (der vel oprindelig er kommet fra Kolding marked) sammen med Peter Andersen, der tillige træffes om foråret med 108 okser for egen regning. Merten Risenberg blev senere en meget anset købmand og rådmand i Flensborg, men medlem af købmandsgildet var han lige så lidt som Jeppe Teglgård. Hans meget store hestehandel (66 i 1485, 46 i 1491 og 45 i 1497) kunne godt tyde på, at også han var udgået fra prangermiljø. I 1491 blev han medlem af Hellig Legemsgildet. Ejendommeligt ser det dog ud, at han allerede i 1481 skulle være optaget i Kalentegildet, hvilket unægtelig tyder på en anseelse, der ikke rigtig rimer med det sene medlemsskab af "skolelavet«. Der er imidlertid usikkerhed omkring optagelserne i Kalentegildet. En del af indførslerne er overstreget igen, og nogle personer er indført flere steder bl.a. Merten Risenberg og hans hustru, der tillige er indfort under 1495, hvilket tidsmæssigt virker ulige mere sandsynligt. ${ }^{24}$

En anden af de usikre indførsler i Kalentegildet gælder Simon Jensen, der ligesom Merten Risenberg første gang træffes 1481, og ligesom denne ses på ny i 1495. Han blev dog medlem af Hellig Legemsgildet allerede i 1476 og af Laurentiusgildet, der fortrinsvis rekrutteredes fra byens jævnere lag, i 1500. ${ }^{25}$ Simon Jensen, der fortoldede 95 okser i oktober 1485, fandt kun optagelse i de gejstlige gilder og har næppe kunnet regnes til købmandsstanden.

"Jens Clausen dictus Lourup « (J.C. som kaldes L.) står der i en grundejerfortegnelse ved en grund beliggende ved Søndertorv. Samme Jens Lourup blev med sin hustru Katherine medlem i Vor Frues købmandsgilde 1485. Samme år fortoldede han 14.oktober 94 okser i Gottorp. Da sønnen Claus Lourup allerede er registreret med 16 okser i 1491, må hans fader antagelig have været en moden mand, måske op i 40'rne, da han omsider i 1485 blev medlem af købmandsgildet. Man tør derfor næppe forvente, at Jens Lourup oprindelig er udgået fra købmandsmiljø. Han har vel sit navn fra Lovrup i Døstrup sogn ved den vestlige oksevej fra Ribe til Tønder og har rimeligvis været pranger, indvandret til Flensborg fra disse vestlige landdistrikter. ${ }^{26}$

Den nævnte Peter Andersen er lidt vanskeligere at placere socialt. Han fandt optagelse i købmandsgildet i 1479 og i Hellig Legemsgildet i 1484. Han træffes endnu i regnskabet 1491 med 185 okser om foråret, men er vist død før 1496. ${ }^{27}$

I modsætning til de hidtil omtalte kan én gruppe med sikkerhed henføres blandt den etablerede købmandsstand, dog næppe til dens førende lag. Det 
gælder bl.a. Lutke og Peter Lutkessen, der muligvis var brødre. De havde begge i 1485 været medlemmer af købmandsgildet en snes år og må antagelig have været 40-50 år i 1485 og formentlig nydt en vis anseelse, siden Lutke i 1492 nævnes sammen med oldermændene blandt de udvalgte i købmandsgildet. De var begge grundejere i byen ${ }^{28}$ I oktober fortoldede Lutke 195 okser, Peter 143 tillige med $42 \mathrm{i}$ august.

Til købmandsstanden må også regnes Hans Kock og Jeppe Torlevsen. De indtrådte i købmandsgildet 1461/62 som de to foregående og har antagelig været deres jævnaldrende. Hans Kock var søn af rådmand Henning Kock, der var blevet medlem af købmandsgildet før 1440 ligesom Torlow Jepsen, der antagelig var fader til Jeppe Torlevsen, hvis søn Henrik blev medlem af købmandsgildet $1483 .{ }^{29}$ Hans Kock fortoldede i 1485110 forårsokser, Jeppe Torlevsen 56 i oktober.

Blandt de yngre fra købmandskredsen er der særlig grund til at hæfte sig ved Peter Nielsen, der senere blev rådmand, og Markvard Holste, der blev borgmester i Flensborg. Markvard blev optaget i købmandsgildet med sin første hustru Katherine i $1478 \mathrm{og}$ må vel derfor have været omkring 30 år, da han den 6.oktober 1485 fortoldede en beskeden flok på 14 okser, der skulle blive starten på en bemærkelsesværdig oksehandlerkarriere. ${ }^{30}$

Peter Nielsen, der også i 1478 blev optaget i købmandsgildet med sin hustru Ingeborg, har antagelig været Markvards jævnaldrende. Ingeborg må have været datter af Jeppe Fink, der allerede i 1477 var anset medlem af det fornemme Kalentegilde. Selv blev hun optaget i gildet sammen med sin mand i 1494 på anbefaling af magister Thomas Fink, der må have været hendes broder. De havde da allerede i 10 år været medlem af Hellig Legemsgildet (1484), som Peter Nielsen altså var optaget $i$, da han i september 1485 fortoldede sine 43 okser, der muligvis stammede fra Ribe marked. ${ }^{31}$

Blandt de nyindtrådte medlemmer i Vor Frues købmandsgilde var Laurens Esbernsen i 1484, Peter Laurensen og Jens Clausen 1485 og Henrik Moller 1486 - alle oksehandlere i Gottorp 1485. Laurens Esbernsen fortoldede 46 okser 1.april og 72 den 14.oktober, han blev medlem af Hellig Legems gildet 1487, men træffes ikke senere. Peter Laurensen fortoldede 16 okser 14/9 og 50 8/10 og er antagelig identisk med Peter Lassen, der i 1491 fortoldede 14 okser $10 / 9$ og $561 / 11$. Kontingenterne svarer utrolig fint sammen. Han var allerede i 1480 blevet medlem af Hellig Legems gildet. Jens Clausen, der blev medlem af Hellig Legems gildet 1480 og i 1489 nævnes med sin hustru, fortoldede 15/10 40 okser og Henrik Moller dagen efter 49 okser. De er formentlig alle yngre folk fra købmandsklassen, der fortoldede kontingenter af mellemstørrelse overvejende om efteråret. ${ }^{32}$

Til købmandsklassen hørte indiskutabelt Hans Matheus, der i 1482 med 


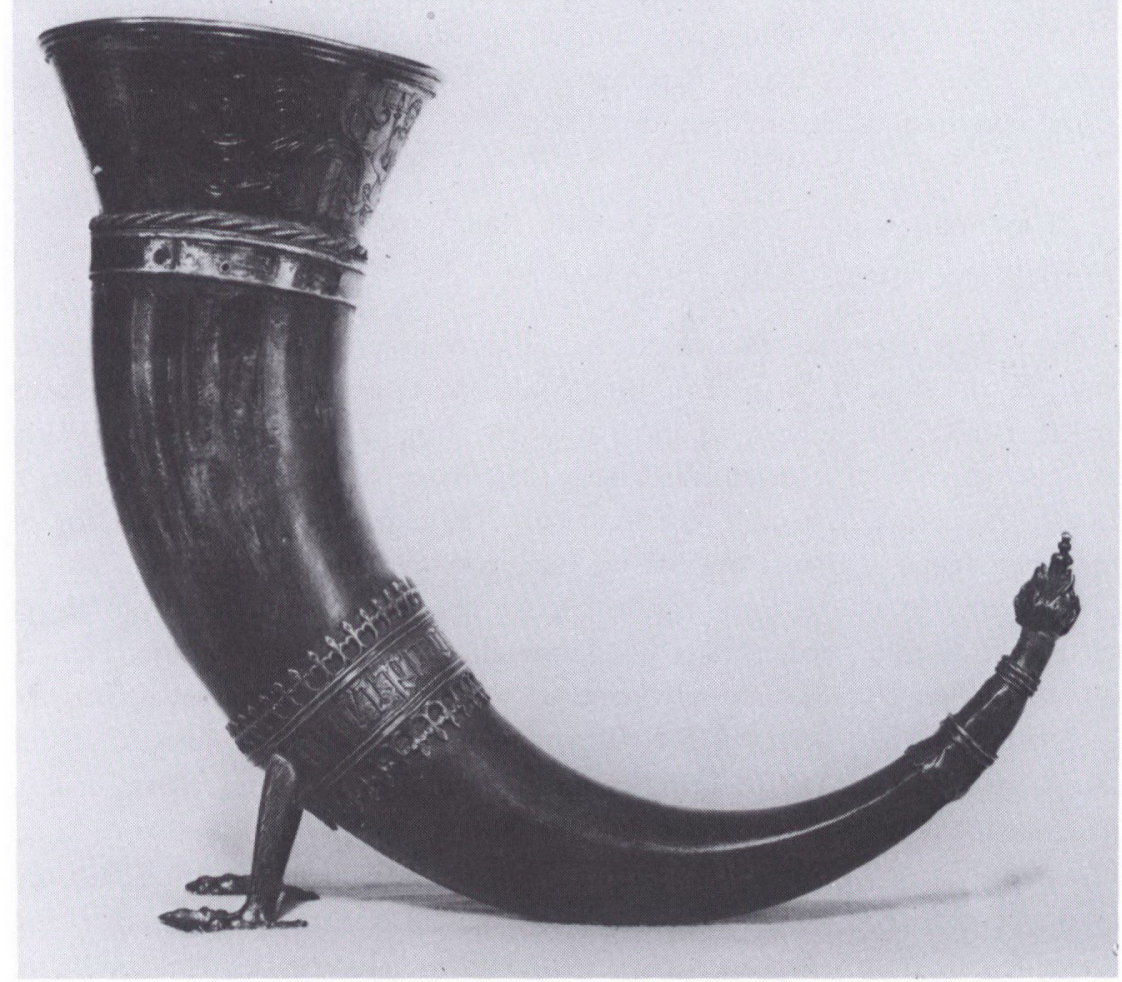

Drikkehorn (hejde $17,8 \mathrm{~cm}$, bredde $24,7 \mathrm{~cm}$ ) fra "den hellige Trefoldigheds Kalentew. Befinder sig $\mathrm{nu}$ pd Flensborg Museum. En indskrift meddeler, at hornet er skanket Flensborg Kalentegilde af Nicolaus Hackstede, der er bevidnet som medlem af gildet mellem 1481 og 1515, altså i den periode, hvor Merten Risenberg, Markvard Holste, Peter Nielsen, Nisse Smit, Ludde Brodersen, Bodil Teglgård, Jens Lourup, Henrik og Hans Holste, Villem Vinberg og Jens Petersen var medlemmer af dette fornemme gilde. Foto i Dansk Centralbibliotek for Sydslesvig.

hustru blev medlem af købmandsgildet. Han var antagelig søn af købmanden af samme navn, der blev optaget i samme gilde i 1462 (eller 1463) ${ }^{33}$ Det er ikke let at sige, om det er fader eller søn, der fortolder en hest 28.januar og 7 okser 15.oktober, men det var sikkert andre varer, der var hovedsagen i hans handel: metalvarer, kramvarer og klæde fortoldede han 23.maj.

Ludde Brodersen, der 14. september 1485 lokaliseres til Flensborg med 60 okser, som antagelig hidrørte fra Ribe marked, indtog en særstilling blandt byens oksehandlere. I 1491 registreres han tillige fra Bredsted og har muligvis en tid været herredsfoged i Nr. Gos herred. Hans fader Broder Froddesen til 
Toftum ejede gods i Hviding herred og blev adlet 1480. I 1492 blev Ludde Brodersen amtmand i Flensborg, og samme år indførte han sin hustru Kirstine i Vor Frues købmandsgilde, hvor han selv havde været medlem siden 1489. I Kalentegildet træffes Ludde Brodersen $1494 .{ }^{34}$ Han må i 1485 have været en yngre mand antagelig i midten af $30^{\prime}$ erne.

\section{Flensborgernes oksehandel i 1491}

Inden 1491 er det tyndet ud i rækkerne blandt de ældre flensborgske oksehandlere. Jeppe Teglgård var holdt op, og Mathias Madsen, Karsten Lund, Hans Kock, Peter Lutkessen og Jeppe Torlevsen hører man ikke mere til. Feltet domineredes nu af Merten Risenberg (260 okser), Ludde Brodersen (246), Lutke Lutkesen (229) og Peter Andersen (185); men ingen magtede dog et opkøb af Jeppe Teglgårds format (se skema 4).

Til denne førende gruppe slutter sig nu Peter Dideriksen, der var blevet medlem af Hellig-Legemsgildet i 1485 og af købmandsgildet i 1486. Han er muligvis tilvandret. Samme navn optræder to gange i regnskabet lokaliseret til Herzogenbosch. Selv om det naturligvis ikke helt kan udelukkes, at der kunne være tale om to forskellige personer, så er lokaliseringsangivelser dog ikke sikrere, end at samme person kan forekomme under f.eks. hjemsted og rejsemål (eller tidligere hjemsted). Peter Dideriksens tilknytning til Flensborg er dog sikker nok. Han ejede grund $i$ byen på hjørnet af Søndertorv og Angelbogade, som senere var i borgmester Villem Vinbergs besiddelse. ${ }^{35}$ Beliggenheden vidner om en ret fremtrædende position.

Byens største oksehandlere var i 1491 alle engagerede i forårsdrivningen, selv om Lutke Lutkessen og Peter Dideriksen også opkøbte i oktober, den sidste tillige i september. Markvard Holste og Jens Lourup, der var startet traditionelt $\mathrm{i}$ oktoberopkøbet fra Kolding marked har nu lagt sig efter forårsdrivning, som - inklusive Ludde Brodersens flokke - bragte Flensborgs andel op imod 1000 okser. ${ }^{36}$

Simon Jensen og Peter Nielsen var som tidligere efterårsdrivere, men hér påkalder de nye navne sig mest opmærksomhed. Den senere borgmester Nisse Smit, der 6.oktober fortoldede så anselig en flok som 100 okser, må antages at være startet engang $\mathrm{i}$ årene mellem $1485 \mathrm{og}$ 1491. Det er ejendommeligt, at Nisse Smit først registreres som medlem i købmandsgildet i 1511 på et tidspunkt, da han for længst var borgmester. Optagelsen gælder utvivlsomt snarere hans nye hustru Anneke. Forgængeren i gildefortegnelsen var borgmesterkollegaen Markvard Holste, der præsenterede sin 2. hustru, borgmesterdatteren fra Kiel Taleke Wulff. I 1490 var Nisse Smit blevet medlem af Hellig Legemsgil- 
det og kun få år senere fandt han optagelse i det fornemme Kalentegilde, omtrent samtidig med Markvard Holste og Peter Nielsen, som han antagelig var jæunaldrende med. ${ }^{37}$

Lidt ældre var sikkert Jeppe Petersen, medlem af købmandsgildet allerede 1472, af Hellig Legemsgildet 1473, i 1480 'erne omtalt i Gertrudsgildet og Laurentiusgildet. Han var oldermand i købmandsgildet i $1492 .{ }^{38}$ Sit okseopkøb fordelte han åbenbart mellem driften fra Ribe og Kolding markeder og foretog tillige et lokalt opkøb på 25 stkr. i november.

Skema 4:

Forårsdrivning 1491:

Ludde Brodersen

Merten Risenberg

Peter Andersen

Lutke Lutkessen

Markvard Holste

Peter Dideriksen

Jens Lourup

Sommerdrivning 1491:

Didrik vame Schilde

Merten Risenberg

Simon Jensen

Peter Lassen
Efterårsdrivning 1491

(sept. + okt.)

Peter Didriksen

Lutke Lutkessen

$80+81$

105

Hans Bondesen $\quad 104$

Mikkel Bondesen $\quad 36$

Nisse Smith

Peter Nielsen

Jeppe Petersen

Simon Jensen

Hans Holste

Tile Lassen

100

56

$59+42$

55

61

44

Hans Risenberg

$\frac{20}{843}$
70

19

$\frac{14}{200}$

Desuden 207 okser i november.

Hans Holste må være Markvards yngre broder, der 1483 blev medlem af Hellig Legemsgildet, men først 1493 af købmandsgildet. Han var i 1511 gift med Herman Vinbergs datter Kathrine. Parret fandt optagelse i Kalentegildet dette år på anbefaling af svigerfaderens broder, Villem Vinberg, der selv 5 år tidligere var anbefalet til samme gilde af Hans' broder Markvard. ${ }^{39}$ Der må have været snævre relationer mellem familierne Holste og Vinberg. I 1505 blev Markvard borgmester og Villem rådmand, i 1517 var også Hans rådmand, og ved Markvards død fulgte Villem ham i borgmesterstolen.

For oksehandelen fik dog Hans og Mikkel Bondesen større betydning. Hans Bondesen, der ud over oktoberokserne fortoldede $60 \mathrm{i}$ november, må have handlet $i$ nogle år før 1491 for at nå op på disse tal. Mikkel, der samme år var blevet optaget i købmandsgildet, må have været ganske ung. Han var $\mathrm{i}$ 
1514 medlem af Laurentiusgildet og nævnes i 1524 i en ejendomsfortegnelse. Hans var 1487 optaget i købmandsgildet, men omtales ikke senere, forsvinder også fra de senere Gottorpregnskaber, hvor Mikkel bliver en hyppig gæst. ${ }^{40}$

Didrik vame Schilde, der i juni fortoldede 97 okser, var velsagtens en tilvandret, der i 1489 blev medlem af købmandsgildet. ${ }^{41}$ Byens sommeropkøb og septemberdrivning var omtrent uændret i 1485 og 1491, forårsdrivningen var steget, og oktoberdriften faldet. Det sidste skal man måske ikke lægge for meget $\mathrm{i}$ - som udviklingslinie.

\section{Flensborgs oksehandlere 1485-91: prangere på vej frem}

Om Flensborgs oksehandlere har man fremhævet, at de tilhørte det høje sociale lag, domineret af borgmestre, rådmænd og fremtrædende købmænd fra byens prominente gilder. ${ }^{42}$ Dette billede dækker unægtelig mindre træffende den kreds af oksehandlere, vi møder i de to ældste Gottorpregnskaber. Selv om Markvard Holste og Nisse Smit ubestrideligt senere blev borgmestre, og Merten Risenberg, Peter Nielsen og Hans Holste ligeså uomtvisteligt senere blev rådmænd, så ændrer det jo ikke ved det faktum, at oksehandlerne i 1485 og 1491 absolut ikke talte repræsentanter fra det øjeblikkelige rådspatriciat.

Og selv om mange af de handlende var medlemmer af byens gilder, så er nok det mest bemærkelsesværdige, at nogle af de aller betydeligste oksehandlere kun var medlem af de gejstlige gilder, derimod ikke - eller først forbløffende sent blev medlem - af købmandsgildet. Det gælder især Jeppe Teglgård og Merten Risenberg, der aldrig blev medlem af købmandsgildet, og Mathias Madsen, Karsten Lund og Jens Lourup, der først nåede at blive medlem i en yderst fremskreden alder. Disse folk med deres store okse- og hestehandel har næppe oprindelig tilhørt købmandsstanden, men må snarere betegnes som prangere. Det samme tør sikkert fastslås om Simon Jensen, og sandsynligvis gælder det flere, f.eks. den Laurens eller Lasse Jacobsen, der tre gange fortoldede mindre kontingenter, i alt 107 okser i 1485, eller den Peter Clausen, der i oktober 1485 fortoldede 86 okser sammen med Haken Hansen. Disse personer kendes i alt fald ikke fra andet kildemateriale i byen. Tile Lassen, der i 1485 fortoldede 25, og i 149144 okser under septemberdriften fra Ribe marked blev i 1495 medlem i Hellig Legemsgildet, men træffes i øvrigt ikke. Den nævnte Haken Hansen blev medlem af købmandsgildet 1484, men da sønnen Ubi eller Ebbi Hakensen allerede optages som medlem i samme gilde 1488 og i november 1491 opkøbte 50 okser, må man antage, at Haken Hansen har haft en længere oksehandelskarriere bag sig før 1485 uden at være medlem af noget gilde. ${ }^{43}$ 


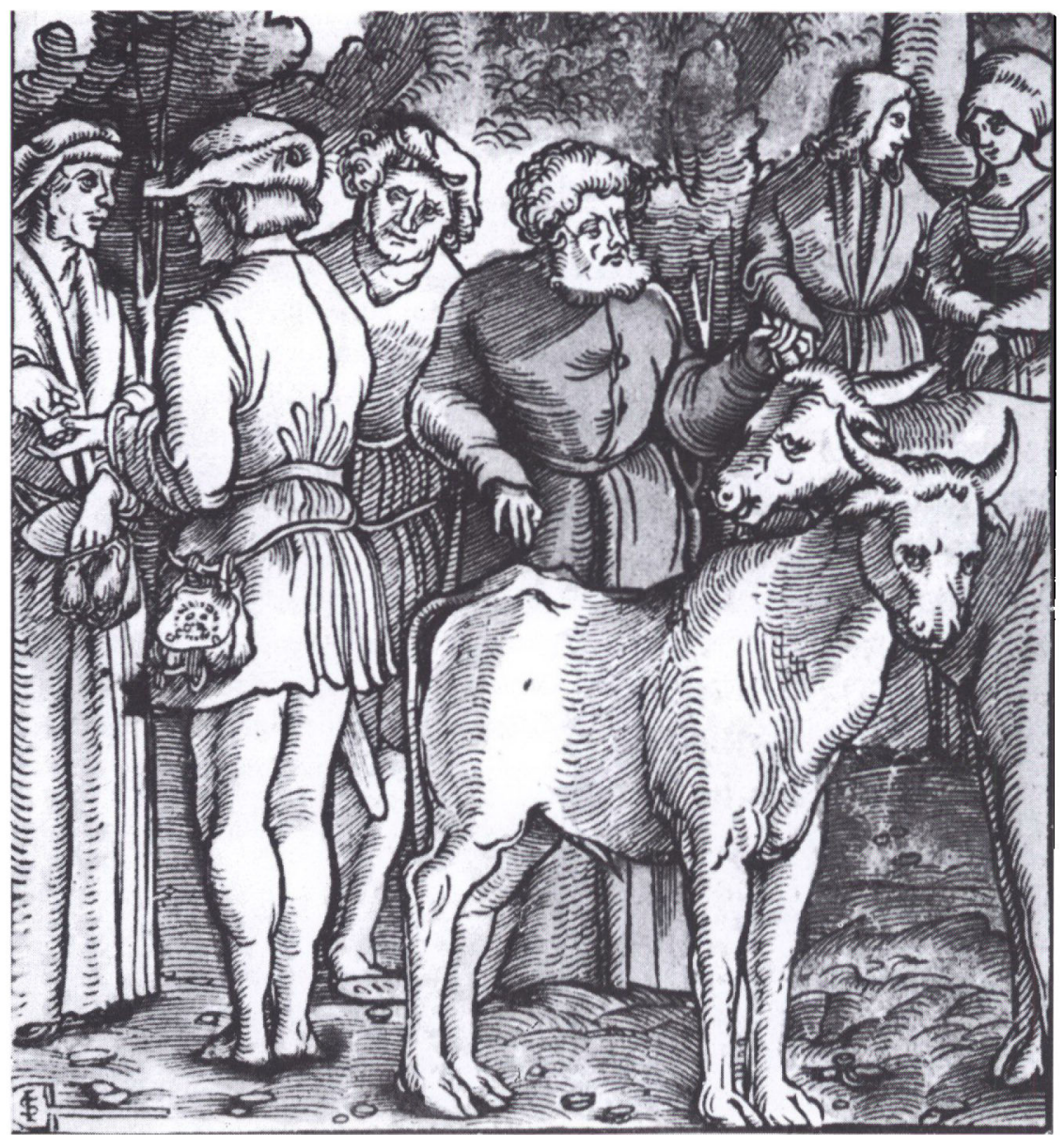

Oksehandel omkring 1500. Fra Staatliche Graphische Sammlung München. Adskillige oksemarkeder là spredt over hele Tyskland og tjente kodforsyningerne til de stor byer. Men billedet af prangere og okser kunne også illustrere en handelssituation $i$ hertugdommerne eller pd et dansk marked. Okserne var smd starke dyr, der kunne tilbagelagge meget lange distancer fra opkabsmarked til slagtning. Men slagteverdien har varet ringe efter vor málestok. Her gengivet efter W.Abel: Geschichte der deutschen Landwirtschaft vom frühen Mittelalter bis zum 19. Jahrhundert, Stuttgart 1962.

Eksemplerne må være tilstrækkeligt til at vise, at der såvel blandt de betydeligste som blandt de mindre betydningsfulde oksehandlere fra Flensborg i disse år fandtes adskillige, der med større rimelighed tør karakteriseres som prangere end henregnes til den egentlige købmandsstand, og af de relativt få handlende, der virkelig var købmænd (f.eks. Lutke og Peter Lutkessen, Hans Kock, Jeppe Torlevsen, Peter Nielsen, Markvard Holste, Hans Matheus, 
sandsynligvis Peter Andersen, Laurens Esbernsen og muligvis Peter Laurensen, Jens Clausen og Henrik Moller) hørte i alt fald i 1485 absolut ingen til byens førende lag.

Der er vist grund til at formode, at Gottorpregnskabet 1485 afspejler tilstande i den flensborgske oksehandel, som har været rådende i den forudgående periode, ja måske endda lader ane en tidligere situation, hvor prangerne i endnu højere grad dominerede handelen, end tilfældet var i 1485. På efterårsmarkederne i Ribe og Kolding domineredes opkøbet af knockenhauere og prangere fra Lybæk, Hamborg og Lüneburg, der varetog opkøbet af byernes slagtekvæg til vinterforrådet. I det omfang handlende fra hertugdømmernes byer, f.eks. Flensborg, gled ind i denne mellemhandel, blev det naturligt en opgave for prangerne, der var vante til det omflakkende rakkerliv på vejene, og som på kvægmarkederne $\mathrm{i}$ de tyske byer skaffede sig den nødvendige kapital til nye opkøb. Heste- og oksehandelen var opkøb, drivning og salg af samme varegruppe og fordrede derfor ikke købmandens generelle vare- og priskendskab, men derimod nok en specialviden om dyrene, som for den sags skyld kunne erhverves i landbruget. Denne baggrund er ganske vel forståelig, men hvorfor blev oksehandelen i den følgende tid $i$ højere grad en opgave for de veletablerede købmænd? Lad os prøve at følge udviklingen.

\section{0'erne og højdepunktet omkring 1500}

Flensborgernes andel af oksehandelen har formentlig holdt sig på mellem 2.000 og 3.000 okser i 1490 'erne. Der er ikke den store forskel på tallene fra 1491 og 1497, hvis forårseksporten har ligget omkr. 1.000; men i de følgende år øges den flensborgske andel kendeligt. Mængde og årsfordeling fremgår af skemaet:

\begin{tabular}{lccrr} 
Skema 5: & & & & \\
& 1491 & 1497 & 1498 & 1501 \\
\hline Forårsdrivning & 974 & $\div$ & 1.185 & 2.009 \\
Sommerdrivning & 186 & 136 & 224 & 85 \\
Septemberdrivning & 197 & 345 & 437 & 713 \\
Oktoberdrivning & 660 & 729 & 1.301 & 1741 \\
Vinterdrivning & 207 & 0 & 63 & 51 \\
\hline & 2.224 & 1.210 & 3.210 & 4.599
\end{tabular}

Både andelen i forårs- og efterårseksporten er steget kraftigt i 1501. I 1491 
havde Flensborg 21 oksehandlere, 1498: 26 og 1501: 30. Men de store oksehandlere havde også forøget deres flokstørrelser:

Skema 6:

\begin{tabular}{lrrllrr} 
& 1498 & 1501 & & 1498 & 1501 \\
\cline { 2 - 3 } \cline { 6 - 7 } Merten Risenberg & 411 & 554 & & Markvard Hesse & 17 & 344 \\
Mikkel Risenberg & 560 & 147 & & Jens Petersen & 61 & 276 \\
Jens Lourup & 462 & 385 & & Peter Dideriksen & 55 & 270 \\
Nisse Smit & 159 & 350 & & Hans Frese & 120 & 158 \\
Markvard Holste & 251 & 250 & & Mikkel Bondesen & 108 & 125
\end{tabular}

Merten og Mikkel Risenberg havde 1490'erne igennem arbejdet deres omsætning op til Jeppe Teglgårds niveau; men 500 okser årligt var ikke længere i særklasse. Tyskerne nåede op i langt større tal. Michel Witte fra Lybæk udførte over 1.000 okser i 1498, Claus Otte fra Hamborg over 900 i 1502 og ca. 850 i 1501, og Hinrick Reyse fra Lybæk fortoldede blot på Kolding marked 766 okser i 1503 og 636 i 1502.

Om Mikkel Risenberg var beslægtet med Merten, tør næppe afgøres. Han var tillige en betydelig hestehandler, der i 1498 fortoldede over 100 heste. Selv om han først blev medlem af købmandsgildet i Flensborg 1504, var han dog så velhavende, at han udlånte penge til hertug Frederiks regnskabsfører på Kieler omslag 1498 og atter i 1499. Hans heste- og oksehandel bragte ham vidt omkring: 1501-06 var han jæunlig gæst på Kolding marked, og i 1503 blev han medlem af Guds legems lavi Ålborg.

Også Merten Risenbergs velstand udviklede sig kendeligt i 1490'erne. Han var - som næunt - i 1495 blevet optaget i Kalentegildet, og 1494 og 1496 skænkede han store beløb i memoriepenge til Vor Frue kirkes fond i byen. Mellem 1487 og 1501 blev han jæunligt næunt for tilgodehavender og gældsposter i stadsprotokollen over borgernes debet- og kreditnoteringer. Han omtales også for økonomiske mellemværender i St. Gertruds kapels formueregnskaber. Han ejede flere huse og grunde i byen og var omkr. 1500 et fremtrædende medlem af det fornemme købmands/skipper-gilde, St. Nicolaigildet. Hans borgerlige anseelse var omsider blevet solidt grundfæstet, og i 1497 omtales han som rådmand. ${ }^{46}$

Hertug Frederik og dennes folk boede i Merten Risenbergs hus og betalte fortæringspenge under deres rejser gennem Flensborg. Han var fast leverandør af f.eks. klæde til hertughoffet og modtog store beløb af Gottorptolderen eller den hertugelige regnskabsfører som betaling for tilgodehavende iflg. regnskab. Han fungerede tillige som bankforbindelse for hertugen, der f.eks. i 1496 lånte $495 \mathrm{mk}$. lybsk til indløsning af Kiel by og slot, der havde været pantsat til 
Lybæk. I 1495 lod hertugen veksle dansk mønt hos ham for ikke mindre end $688 \mathrm{mk}$. lybsk og det følgende år for $300 \mathrm{mk}$. lybsk. Merten Risenbergs opkøbshandel i Danmark må have været særdeles omfattende, siden han kunne anvende så store beløb i dansk mønt. Der er næppe tvivl om, at han må have været Flensborgs mest velhavende købmand i årene op til 1500. Han omtales ikke efter 1501, og siden hustruen er registreret i Husumregnskabet 1505 , er Merten åbenbart død i sin velstand. ${ }^{47}$

Også Markvard Holste og Nisse Smit må have tjent store penge på oksehandel i 1490'erne. I 1495 kunne Markvard veksle danske penge for hertug Frederik til 420 rh.gl. (= $560 \mathrm{mk}$. lybsk). Han medbeseglede jævnligt kontrakter indgåede mellem hertugdømmets adelige godsejere om pantsættelse eller salg af gårde, f.eks. 1494 for Hans von Andersen i Kar herred, 1496 for Detlev v.d. Wisch angående 35 gårde i Slogs, Rise og Sdr. Rangstrup herreder og 1497 for Eggert Gjordsen på Solvig om salg af 5 gårde i Kær herred. Den tillid, han nød i udbredte adelige kredse $i$ hertugdømmerne, vidner især om hans udbredte okseopkøb. Han ejede mindst to huse på østsiden af Storegaden i St. Nicolai sogn ud imod fjorden. Allerede i 1494 omtales han som rådmand, og Nisse Smit, der også besad flere ejendomme både i Frue og i Nicolai sogn, må vel også være indtrådt i rådet i 1490'erne, siden han blev borgmester allerede $1505 .^{48}$

Jens Lourups store oksehandel gjorde ham i 1490'erne til en anset borger i Flensborg. Han ejede flere grunde i Nicolai sogn, og i 1495 blev han medlem af Kalentegildet tilmed på anbefaling af selveste borgmester Arnt Kiessenbrugge. Jens Lourup bevidnede sammen med Markvard Holste, Merten Risenberg og Claus Ankersen fra Haderslev Eggert Gjordsens forannæunte salgsbrev på de 5 gårde til Hans Rantzau. Det er utvivlsomt hr. Eggerts største okseaftagere, vi hér træffer. ${ }^{49}$

\section{Forårsdrivningen i 1490'erne}

Der var betydelig kontinuitet i forårsdrivningen i årene omkr. 1500, men tillige tilgang i forårsdrivernes antal, således som det fremgår af skema 7 på næste side.

De største oksehandlere var alle engagerede $\mathrm{i}$ forårsdrivningen. Foruden Merten Risenberg, Jens Lourup, Markvard Holste, Peter Dideriksen og Nisse Smit holdt af de ældre også Ludde Brodersen og Lutke Lutkessen ved endnu. Merten Mikkelsen og Markvard Hesse var nye unge folk, der endnu ikke var medlemmer af købmandsgildet. Merten blev medlem i 1504 samtidig med Mikkel Risenberg, Markvard året efter. ${ }^{50}$ Boye Payesen var født $1472 \mathrm{og} b l e v$ 
Skema 7:

\begin{tabular}{|c|c|c|c|c|}
\hline Forårsdrivning & 1498 & 1501 & Forårsdrivning & 1501 \\
\hline Merten Risenberg & 218 & 249 & Ludde Brodersen & 122 \\
\hline Jens Lourup & 206 & 251 & Lutke Lutkessen & 57 \\
\hline Markvard Holste & 146 & 250 & Jens Petersen & 89 \\
\hline Peter Dideriksen & 55 & 270 & Henrik Holste & 58 \\
\hline Nisse Smit & 89 & 170 & Boye Payesen & 69 \\
\hline Mikkel Risenberg & 206 & 147 & Tort Jepsen & 23 \\
\hline Markvard Hesse & 17 & 144 & & 418 \\
\hline Nisse Jensen & 66 & 110 & & \\
\hline Merten Mikkelsen & 118 & 1591 & & 418 \\
\hline Laurens Tygesen & 64 & & & 1591 \\
\hline 10 handlende & 1185 & & 14 handlende & 2009 \\
\hline
\end{tabular}

medlem af købmandsgildet 1497 med sin hustru, Dorothea, datter af den ansete Flensborgkøbmand Junge Ketel, der omtales som medlem af Kalentegildet 1504. Tord Jepsen må have været ganske ung, da han blev medlem af købmandsgildet 1496. Hans tid hører det følgende århundrede til. ${ }^{51}$

Lidt ældre var Jens Petersen, Laurens Tygesen og Henrik Holste. Jens Petersen kom i købmandsgildet allerede 1478, samtidig med Markvard Holste, Laurens Tygesen i 1490 og Henrik Holste i $1491 .{ }^{52}$ Henrik var muligvis yngre broder til Markvard, der anbefalede hans optagelse i Kalentegildet 1497. Han var allerede blevet medlem af Hellig Legemsgildet i 1494. Jens Petersen blev optaget i Hellig Legemsgildet 1484 og i Kalentegildet i 1508 på anbefaling af den allerede omtalte Peter Nielsen, som må have været hans jævnaldrende og i 1508 var blevet rådmand. Jens Petersen nød stor anseelse og var garant for flere nye medlemmer $i$ købmandsgildet. ${ }^{53}$ Laurens Tygesen blev medlem af Hellig Legemsgildet og Laurentiusgildet i 1502, året efter gjorde han regnskab i Nicolaigildet, hvor også Henrik Holste, Boye Payesen og Tort Jepsen var virksomme. I 1505 var Tygesen udpeget som dommer $i$ en sag for rådet tillige med Peter Nielsen og Jens Petersen og rådmændene Brun Buckenberg, Peter Rudbæk, Villem Vinberg og borgmestrene Markvard Holste og Nisse Smit. ${ }^{54}$

Det er tydeligt, at disse nye forårsdrivere hørte til det velanskrevne borgerskab. Markvard Hesse, Jens Petersen, Boye Payesen og Tort Jepsen endte alle i rådmandsstolen. 


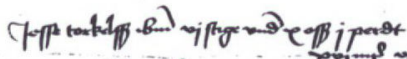

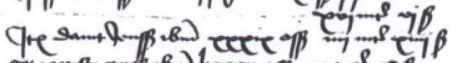

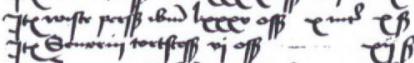

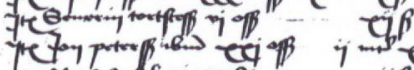

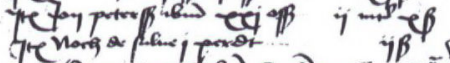

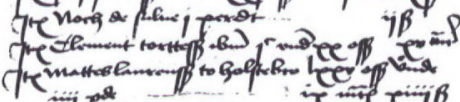

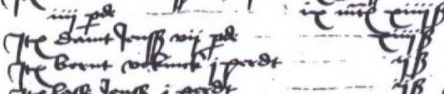
frefl

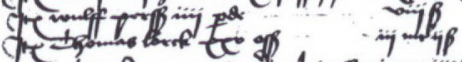

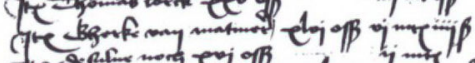

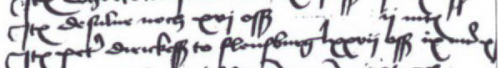
dectorestion tiripmater

-

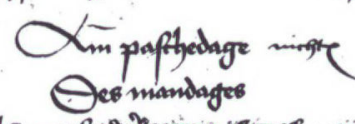

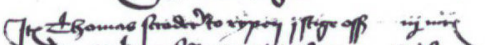

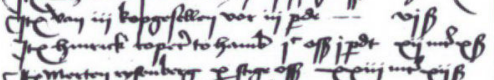

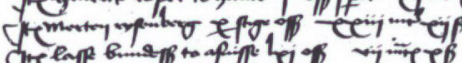

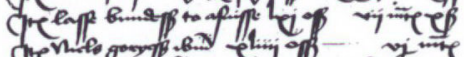
gen

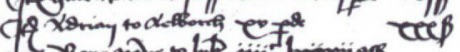

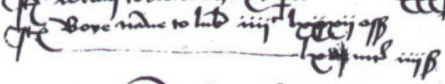

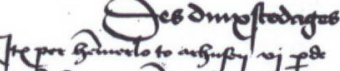
qreporis

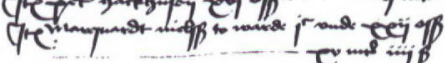

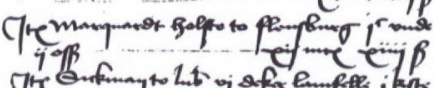
Therifurat Odma ir elias ing

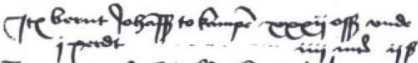

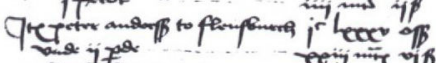

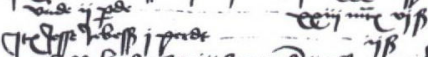

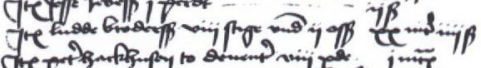

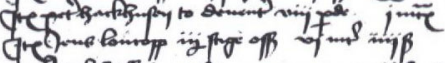

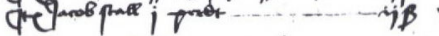

\section{Oesmiotruederio}

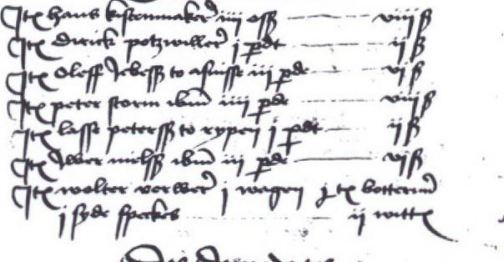

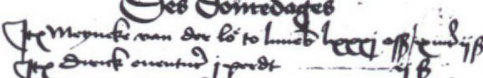

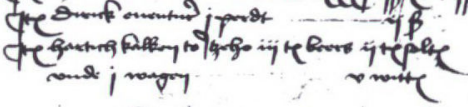

$$
\text { i vangy }
$$

\section{Oes bridages}

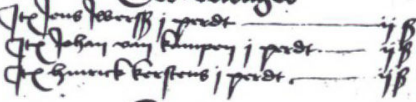

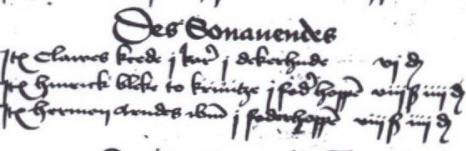

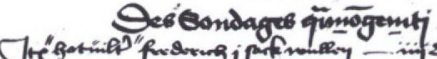

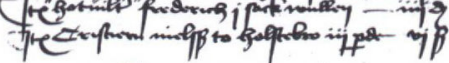

$$
\begin{aligned}
& \text { Oec mandanges }
\end{aligned}
$$

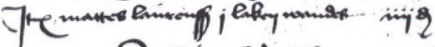

$$
\begin{aligned}
& \text { Qte simprestinges }
\end{aligned}
$$

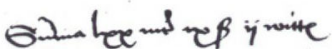




\section{Efterårsdrivningen i 1490 'erne}

Også i efterårsdrivningen udviste deltagelsen fra Flensborg stor kontinuitet. 6 handlende træffes i 1497, 1498 og 1501 og 15 handlende træffes $i$ to af de tre regnskaber, således som det fremgår af vedføjede skema:

Skema 8:

Efterårsdrivning (sept./okt.)

$\begin{array}{lrrrlrr} & 1497 & 1498 & 1501 & 1497 & 1498 & 1501 \\ \text { Merten Risenberg } & 20 & 163 & 305 & \text { Jens Lourup } & 256 & 135 \\ \text { Lutke Lutkessen } & 83 & 91 & 129 & \text { Peter Nielsen } & 38 & 74 \\ \text { Mikkel Bondesen } & 174 & 108 & 74 & \text { Jens Luddesen } & 62 & 64 \\ \text { Nisse Smit } & 101 & 70 & 180 & \text { Peter Lassen } & 26 & 58 \\ \text { Lutke Petersen } & 70 & 83 & 174 & \text { Hans Frese } & 120 & 158 \\ \text { Nis Fivians } & 19 & 42 & 69 & \text { Henrik Holste } & 58 & 88 \\ \text { Markvard Holste } & 43 & 100 & & \text { Simon Jensen } & 55 & \\ \text { Jeppe Petersen } & 30 & 51 & & \text { Ludde Brodersen } & 63 & \\ \text { Mikkel Risenberg } & 240 & 245 & & \text { Ubi Hakensen } & 52 & \\ \text { Edde Brodersen } & 48 & 57 & & \text { Henrik Smit } & & 26 \\ \text { Find Olufsen } & 70 & 29 & & \text { Claus Teglgård } & & 140 \\ \text { Markvard Hesse } & 21 & & 200 & \text { Herman Vinberg } & & 99 \\ \text { Peter Klockengeter } & 61 & & 33 & \text { Tort Jepsen } & & 36 \\ \text { Erik Lange } & 21 & & 79 & \text { Laurens Tygesen } & & 94 \\ \text { Claus Guldsmed } & 18 & & 12 & \text { Ebbi Jepsen } & & 40 \\ & & & & \text { Jens Petersen } & & 187\end{array}$

Drivning i september/oktober beskæftigede i 149716 handlende med 1.074

De to regnskabssider pd modstående side er hentet fra Gottorpregnskabet 1491. Den forste side indledes med "Jesse torkelss ibidem vj stige vnde $x$ oss $j$ perdt $x v j$ mrk vj sw. Endelsen ss angiver -ssen f.eks $i$ patronymikonendelser eller $i$ "ossen " ( $=$ okser). Mangdebetegnelsen stige $=s$ snes $=20$ stk. Montangivelsen mrk (= mark) svarer til $16 s$ (= skilling). Da toldtaksten var $2 s$ pr. okse eller hest, står der "Jesse Torkelsen ibidem 130 okser I hest 16 mark 6 skilling." Ibidem betyder samme sted fra som forannaunte. Af foregående side fremgår, at fortoldningen galder en rakke prangere hjemmehorende $i$ Ribe. Her ses ogsd, at posterne er dateret påskeaften (= lerdag for pdskedag), hvilket i 1491 var 2. april.

Nastsidste post denne dato er "Peter dirickess to flensburg 77 oss 9 mrk $10[\mathrm{~s} /$ ". Påskedag fortoldes intet, mandag 4. april traffes som nr. 4: "Merten rysenberg $9 \frac{1}{2}$ stige oss 23 mrk $12 \mathrm{su,} \mathrm{og} \mathrm{dinxstedages}$ $\left(=\right.$ tirsdag 5. april) som nostsidste post pd siden: "Marquardt Holste to flensburg $I^{c}(=100)$ vide ij oss (altså 102 okser) $12 \mathrm{mrk} 14 \mathrm{sw}$.

På naste side er post nr. 2: „Peter anderss to flensburch 185 oss vnde 2 perde 23 mrk 6 si. Post nr. 4:

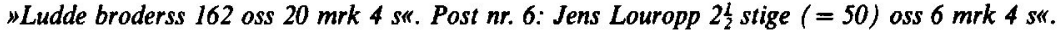

Rigsarkivet foto. 
okser, i 149820 handlende med 1.738 okser og i 150122 handlende med 2.454 okser. De store forårsdrivere Merten og Mikkel Risenberg, Jens Lourup, Markvard Holste og Nisse Smit udførte også kontingenter om efteråret. Kun Peter Didriksen synes nu udelukkende at have helliget sig forårsdrivningen, mens Mikkel Bundesen var og blev efterårsdriver. Han handlede i øvrigt også med heste, får, lam og svin, så hans udgangspunkt var muligvis kreaturhandel på landet. I 1497 var han engageret i en hestehandel i Stade, men i 1506 fortoldede han heste i Plön, så da var målet åbenbart Lybæk. ${ }^{55}$

Lutke Lutkessens oksehandel lå også overvejende i efteråret, og Peter Nielsen, Jeppe Petersen, Peter Lassen og Simon Jensen var udelukkende efterårsopkøbere, ganske vist $\mathrm{i}$ et mere beskedent omfang. Af de nye oksehandlere, der kom til i 1490'ernes forårsdrivning, handlede Jens Petersen, Laurens Tygesen, Markvard Hesse, Henrik Holste og Tort Jepsen også okser om efteråret, medens Merten Mikkelsen, Nisse Jensen og Boye Payesen foreløbig har koncentreret sig om forårsafsætningen.

Mange af de nye efterårsdrivere var ikke helt unge folk i slutningen af 1490'erne. Det gjaldt således Hans Frese, Edde Brodersen, Nis Fivians og den allerede omtalte Herman Vinberg. Hans Frese blev medlem af købmandsgildet i 1490 , men allerede i 1480 'erne træffes han flere gange i Laurentiusgildet og blev optaget allerede 1475 i Hellig Legemsgildet. ${ }^{56}$ Han træffes i Gottorp 1485 med 1 hest. Han må derfor have været en mand i 40'rne, da han i 1490'erne byggede sit anselige okseopkøb op. Nis Fivians blev medlem af Hellig Legemsgildet i $1481 \mathrm{og}$ af købmandsgildet 1484, og i 1503 lånte han penge i Nicolaigildet. Edde Brodersen og Herman Vinberg blev optaget i købmandsgildet 1486. ${ }^{57}$ Edde Brodersens oksehandel var dog beskeden sammenlignet med hans omfattende hestehandel. Med heste og klædevarer træffes han allerede i Gottorpregnskabet 1491, så han kan antagelig senest være født $\mathrm{i}$ begyndelsen af 1460'erne. Efter 1501 forsvinder han fra regnskaberne.

Herman Vinbergs fader Hans Vinberg blev optaget i købmandsgildet i 1473 med hustruen Anneke, der var søster til borgmester Haye Payesen, der i 1473 måtte udstede orfejdebrev til Christian I $\mathrm{i}$ anledning af sin deltagelse $\mathrm{i}$ oprøret 1472. Herman Vinberg var sandsynligvis ældre end broderen Villem og må derfor formodes at være født $i$ slutningen af 1450 'erne, og datteren Katrine, der ægtede Hans Holste før 1511, må antages at være født før $1490 .{ }^{58}$ Datteren Leneke, der åbenbart endnu ikke var voksen i 1510, da hun nævnes sammen med forældrene i listen over Laurentiusgildets medlemmer, havde før 1519 ægtet hestehandleren Merten Kordes. Herman Vinberg spillede en meget fremtrædende rolle i det ansete skipper- og købmandsgilde, St. Nicolaigildet, hvis nye gildeskrå han udarbejdede år $1500 .{ }^{59}$

Til de yngre folk, Markvard Hesse og Tort Jepsen, der opkøbte både 
forår og efterår, kan også henregnes efterårsdriverne Lutke Petersen og Jens Luddesen (ell. Ludiksen), der blev medlem af købmandsgildet $i$ henholdsvis 1495 og 1493 begge med deres hustruer, så de er dog nok fødte før $1470 .^{60}$ Lutke Petersen var antagelig søn af den omtalte Peter Lutkesen, der indtrådte i købmandsgildet 1462 og drev okser i 1485. Deres betydning som oksehandlere af mellemniveau må have ligget i 1490'erne og de første år af 1500-tallet. I 1508 træffes deres oksehandel ikke længere.

Claus Teglgård må være identisk med forannævnte Nisse Teglgård, der blev medlem af købmandsgildet 1490 og som antagelig var søn af Jeppe og Bodil Teglgård. Af hans to poster i 1501 kan de 72 okser fortoldet i Gottorp 15/10 følges tilbage til Kolding Francisci marked 1501, hvor han fortoldede 74 okser, utvivlsomt de samme dyr. På Ribemarked samme år er han ikke registreret; men derfor kan de 68 okser, han fortoldede i Gottorp 16/9 meget vel hidrøre derfra, men blot være opkøbt på ruten sydover. I alt fald handlede han i Ribe, hvor han 1505 er registreret med klæde og heste og 1506 atter med heste, så han har åbenbart fortsat faderens handel, men tilsyneladende i mere beskedent omfang i 1490 'erne og begyndelsen af 1500-tallet; en retssag 1513 kaster lys over en hestehandel mellem ham og en anden flensborger. ${ }^{61}$

Claus Goldsmit og Peter Klockengeter kan ikke henregnes til købmandsstanden. Den første hed Claus Ekelef og var guldsmed, selv om han fandt optagelse i købmandsgildet 1486. Han var dog tillige oldermand i guldsmedenes, malernes, snedkernes og glarmestrenes forenede lav. Mester Peter eller Peter Hansen var klokkestøber, hvilket fremgår af flere toldposter med kobber og metalarbejder i Gottorp- og Plönregnskaberne. Han leverede klokker og døbefonte til kirker overalt i Nordjylland bl.a. en endnu eksisterende døbefont i Århus domkirke. Han betaltes tilsyneladende til dels med heste og okser, som han forhandlede, sandsynligvis en tidstypisk kombination af håndværk og handel. ${ }^{62}$

Find Olufsen, der fortoldede små oktoberflokke i Gottorp 1497 og 1498, træffes 1496 12/10 med 12 okser i Plön, så han afsætter åbenbart i Lybæk. Han blev optaget i Hellig Legems gildet 1496, var derimod så lidt som Erik Lange og Henrik Smit medlem af Vor Frues købmandsgilde. De synes alle tre at have ejet hus $\mathrm{i}$ byen, og Erik Lange lånte penge i St. Gertrudsgildet mod pant $i$ sit hus. De tilhørte næppe den egentlige købmandsstand. ${ }^{63}$

\section{Flensborgs oksehandlere i 1490'erne: alsidige storkøbmænd}

Selv om Hans Bondesen i slutningen af 1480'erne og Mikkel Bondesen fra begyndelsen af 1490'erne måske har udviklet deres kvæg- og hestehandel fra 
en slags landhandel, og selv om Mikkel Risenbergs store heste- og oksehandel peger imod en begyndelse mere som pranger end som købmand, så kom dog for alvor købmændene med i oksehandelen i løbet af 1490'erne med folk som Peter Dideriksen, Markvard, Hans og Henrik Holste, Nisse Smit, Peter Nielsen, Jens Petersen, Laurens Tygesen, Hans Frese, Nis Fivians, Edde Brodersen, Herman Vinberg og Boye Payesen, der alle helt indiskutabelt må henregnes til købmandsstanden. Det kan tillige med stor sikkerhed antages om Lutke Petersen og Jens Luddesen og om den nye generation, der trådte til omkring århundredskiftet med folk som Markvard Hesse og Tort Jepsen.

Men de tidligere prangere Merten og Mikkel Risenberg udbyggede i høj grad deres tidligere måske lidt ensidige heste- og kreaturhandel i løbet af 1490'erne til en alsidig og velassorteret varehandel, der tillod dem omfattende leverancer til hertughoffet. Nøglen hér er sandsynligvis indkøb i udlandet af fremmede klædesorter som returvarer for heste og okser, hvilket gav de tidligere prangere indpas $i$ en langt mere indbringende varehandel, der tillod dem at øge deres okse- og hesteopkøb, så omsætningen og fortjenesten kunne væsentlig udvides. Forudsætningen var naturligvis, at det øgede kontingent af dyr med sikkerhed kunne påregne afsætning; men hér lå chancerne for dem, der involverede sig i den stærkt stigende forårsdrivning, hvis dyr fandt afsætning på forårsmarkeder i Nordvesttyskland og Nederlandene f.eks. i Deventer og Zwolle, hvor hollandske klædeforhandlere frekventerede kreaturmarkederne. ${ }^{64}$

Allerede i 1485 træffer vi foruden Flensborgs professionelle klædekøbmænd i Gottorp tillige oksehandlerne Merten Risenberg, Jeppe Teglgård, Jens Lourup og Jeppe Torlevsen med store klædeposter, oftest i rimelig tid efter eller før en oksepassage. Merten Risenberg kom săledes 21.april med 2 pakker klæde ca. en måned efter hans og Teglgårds oksedrift 22.marts, og Jeppe

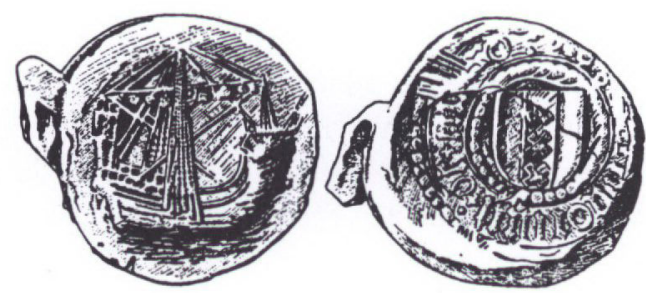

Kladeplomber var kontroltegn af bly formet som to plader, der pressedes imod hinanden. Plomben var forsynet med stempel, der angav tilvirkningsstedet og altså fungerede som varekontrol og samtidig blev $k$ valitetsgaranti. Disse kladeplomber er fundet $i$ stort tal overalt $i$ Norden som vidnesbyrd om den udbredte kladehandel, der kun har efterladt sig fä spor i form af vareprover. Billedet viser en kladeplombe fra Amsterdam, der findes på Stockholms stadsmuseum. Gengivet efter Kulturhistorisk Leksikon for Nordisk Middelalder XIII sp. 330 (fig. 3). 
Teglgård fortoldede 17.juni 1 klædepakke tre uger - en måned efter hans store hesteposter 21. (44 hester) og 24. maj (65 heste). I 1491 fortoldede Markvard Holste 1 korsbånd med klæde den 10.maj som returfragt for 102 okser, han fortoldede 5.april, og Merten Risenberg kom 27.maj samme år med 2 korsbånd som returfragt for 190 okser fortoldet 4.april. Omvendt gav salget af klædet Merten kapital til nyt opkøb af 70 okser, som han fortoldede 6.juli. Peter Dideriksen fortoldede åbenbart normalt klæde i Gottorp i februar måned, i 1501 således 12. og 19.februar 2 pakker selv og 2 ved en handelstjener. Salget af klædet gav Peter Dideriksen penge til opkøb af okser til forårsdriften, i 1501 i alt 270 okser fortoldet 26. og 29.marts. Der kunne gives en lang række eksempler på dette tydelige samspil mellem tidspunkterne for heste- og oksedrivning og fortoldninger for store klædeemballager som returfragt. ${ }^{65}$ I 1491 var Merten Risenberg, Markvard Holste, Hans Bondesen og Edde Brodersen engageret i klædeimporten. I 1498 var Peter Dideriksen, Jeppe Petersen, Mikkel Risenberg og Lutke Petersen kommet til, og i 1501 desuden Nisse Smit, Nis Fivians, Henrik Holste, Mikkel Bondesen og Jens Ludekessen.

Der er næppe tvivl om, at det især var forårsdrivningen med kontakter til nederlandske klædeforhandlere, der har lettet prangere som Jeppe Teglgård, Merten og Mikkel Risenberg og måske tillige Jens Lourup overgangen til den egentlige købmandsklasse i det helt store format i løbet af 1480'erne og navnlig 1490 'erne. Plönregnskaberne fra 1490 'erne viser, at flensborgerne ikke førte klædeemballager ad denne rute fra Lybæk, og Merten Risenbergs klædeleverancer til hertughoffet var karakteristisk nok Leidisk klæde, der netop begyndte at vinde indpas $\mathrm{i}$ hertugdømmerne og Danmark i årene omkr. $1500 \mathrm{og}$ i de følgende 2-3 årtier fik en helt dominerende position i klædedistributionen herhjemme. ${ }^{66}$ Denne udvikling må netop relateres til forårseksporten af okser til de nederlandske markeder, en udvikling, som specielt flensborgerne førte an i, men som hurtigt blev fulgt op af danske okse- og klædehandlere, navnlig fra Ribe.

\section{Flensborgs oksehandel: værdi og betydning}

Hvilken værdi havde mon den flensborgske oksehandel i årene omkr. 1500 ? I okt. 1499 betalte hertug Frederiks regnskabsfører 1221/2 mk. lybsk for 49 fynske okser, hvilket giver en gennemsnitspris på $2 \frac{1}{2} \mathrm{mk}$. lybsk, men i april 1499 gav han $6 \mathrm{mk}$. lybsk parret for magre forårsokser, så det er muligt, at prisen for forårsokser bør sættes en anelse højere end for efterårets græsøksne. I nov. 1501 købte regnskabsføreren 53 okser af en viborgkøbmand til en gennemsnitspris på $2 \mathrm{mk}$. 14 sk. lybsk. I Gottorpregnskabet fra 1501 forekom- 
mer indkøbspriser for 2 partier på 46 og 55 okser til gennemsnitspriser på henholdsvis $3 \mathrm{mk}$. $31 / 2 \mathrm{sk}$. og $3 \mathrm{mk}$. 1 sk. pr. okse i lybsk mønt. Om priserne er svagt stigende eller udtryk for kvalitetsudsving er svært at sige. Små prisudsving forekom, som det fremgår af et hertugeligt indkøbsregister omfattende 234 okser, der er søgt tidsfæstet til ca. 1490, men antagelig snarere bør henføres til slutningen af 1490'erne. Priserne i lybsk mønt svinger mellem $2 \frac{1}{4}$ og $33 / 4$ mk., men yderpriserne er sjældne. 217 af okserne svingede mellem $2 \frac{3}{4} \mathrm{mk}$. og 3 mk. 6 sk., og gennemsnitsprisen for alle 234 bliver næsten præcis $3 \mathrm{mk}$. lybsk, som utvivlsomt må være en brugbar gennemsnitspris for okser i hertugdømmerne i årene omkr. $1500 .^{67}$ Med denne beregningsnøgle vil de flensborgske oksekontingenter i 1498 andrage en værdi på ca. 10.000 og i 1501 på ca. $14.000 \mathrm{mk}$. lybsk. Til sammenligning kan måske tjene, at Kiel by, slot og fogderi i 1496 blev indløst fra rådet i Lybæk for en sum af $28.635 \mathrm{mk}$. lybsk, hvilket var den største af enkeltpantekravene, der ved delingen i 1490 resterede på hertugdømmerne, endog større end pantesummen på $18.000 \mathrm{mk}$. lybsk, for øen Femern med slottet Glambæk. ${ }^{68}$

Flensborgs største oksehandlere som Merten og Mikkel Risenberg kunne i slutningen af 1490 'erne mobilisere en årlig eksport, der i værdi let løb op i $1500 \mathrm{mk}$. lybsk, og mellem 500 og $1.000 \mathrm{mk}$. lybsk var absolut ikke ualmindeligt, således som skema 6 viser. Hvis dertil skal lægges over 100 heste, som Mikkel Risenberg præsterer i 1498, når man op i langt større beløb.

Da hestepriserne svingede stærkt, vil en gennemsnitspris skulle tages med stort forbehold. Det var dog næppe helt billige landkrikker, der gik til prangernes udenrigsomsætning. Mikkel Risenberg solgte selv i 1498 en »telter " (damehest) til hertughoffet for $24 \mathrm{mk}$. lybsk, og i 1495 fik Thomas Lorck fra Haderslev 19/2 mk. lybsk ligeledes for 1 telter. I 1496 havde lybækkeren Lutke Moller, der var en god kending af tolderen i Gottorp, mistet 8 heste på denne rute, som værdisættes til $200 \mathrm{mk}$. lybsk, altså i gennemsnit $25 \mathrm{mk}$. lybsk pr. hest. Den lybske hestepranger Hinrik Reyse, der ligeledes var hyppig gæst i Gottorp, har i 1500 mistet 2 heste mellem Lybæk og Hamborg til 51 mk. lybsk, og Lutke Moller havde i 1502 mistet 4 heste mellem Hamborg og Ulzburg til $60 \mathrm{rh}$. gyl. (= $80 \mathrm{mk}$. lybsk), og en anden lybækker havde mistet 3 heste samme år til $50 \mathrm{rh} . \mathrm{gl} .^{69}$

Selv om man anslår en forsigtig gennemsnitspris på 15-20 mk. lybsk, vil værdien af 100 heste altså sagtens kunne måle sig med de største årskontingenter af okser. Det var virkelig store værdier, disse flensborgske storeksportører havde bundet $i$ deres store dyreflokke. Til sammenligning kan anføres, at den holstenske godsejer Detlev v.d. Wisch i 1496 solgte 35 gårde og en mølle i Slogs, Rise og Sdr. Rangstrup herreder for $4.900 \mathrm{mk}$. lybsk, året efter solgte Eggert Gjordsen 5 gårde i Kær herred for 1640 mk. lybsk, og i 1499 solgte 
en flensborger 6 gårde i Mølmark i Sørup sogn (Nye herred) for $1.200 \mathrm{mk}^{70}$ Merten og Mikkel Risenbergs årsflokke af okser har altså haft en værdi, der måske kunne sidestilles med værdien af 5-6 gårde.

Men hvor stor en værdi repræsenterede de klædeemballager, der ofte var returfragt: laken wandes, packen laken eller packen wandes? Hvad var en terling laken eller et krutzeband, der også kunne rumme klæde? De flanderske, brabantiske og engelske klædesorter lå oftest i stykker (laken) på ca. 3 alen bredde og 40-45 alen længde, mens de hollandske sorter gerne lå $i$ halv længde 20-22 alen. De såkaldte terling, der var langt de hyppigst forekommende klædepakker, havde omtrent fast mål ved år 1500, nemlig ca. 20 stykker af de lange laken eller ca. 40 stykker af de korte laken, altså 8-900 alen klæde. Det var dog ikke alle pakker, der holdt terlingmål. Korsbånd angav en særlig pakkeform, der intet siger om indhold og størrelse. ${ }^{71}$

I 1494 leverede Merten Risenberg Leidisk klæde til hertughoffet til $21 \mathrm{mk}$. 4 sk. lybsk pr. laken eller klædestykke (à $3 \times$ ca. 20 alen), og i 1497 solgte han Leidisk i alenmål til 18 sk. lybsk pr. alen, hvorved et stykke Leidisk ville koste

Kladehandel vist på et trasnit fra Grammateus: Rechnung auf Kaufmannschafft (Nürnberg 1518). Medens kobmanden modtager betalingen og forer handelen $i$ sin regnskabsbog, maler handelstjeneren det bestilte alenmal ud af kladerullen, den sdkaldte laken wandes. Flere kladeruller ligger pà hylderne i lagerlokalet bag portàbningen. Gengivet efter Illustrierte Geschichte der deutschen frühbürgerliche Revolution. Dietz Verlag Berlin 1974 s. 23.

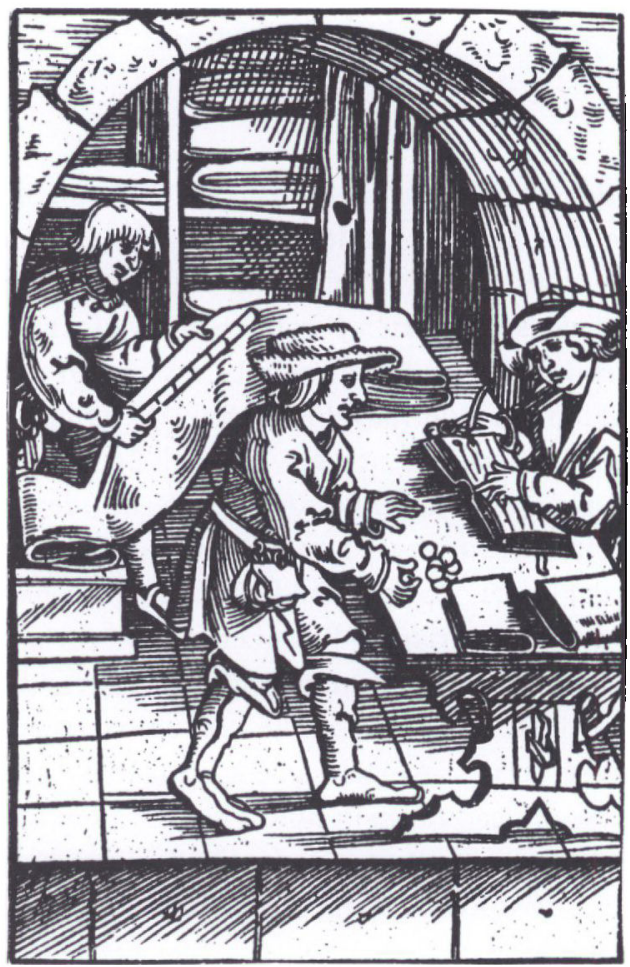




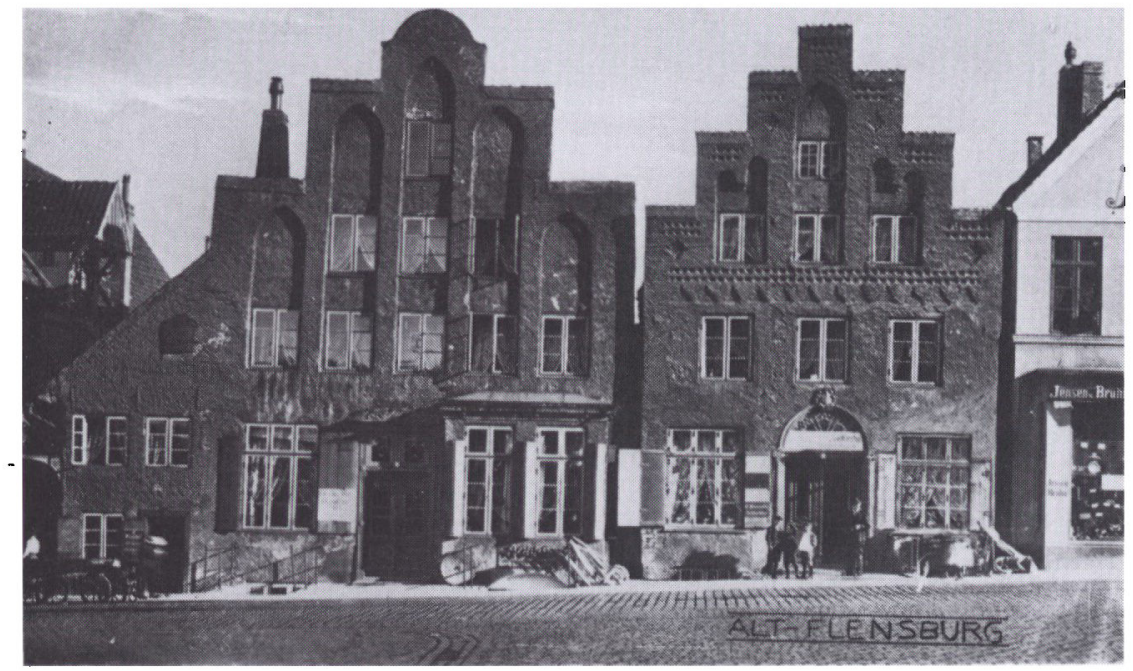

Flere af de storste oksehandlere boede i de solide stenhuse rundt om Sondertorv $i$ Flensborg. Her boede saledes Merten Risenberg, Wilhelm Vinberg og klokkestøber Peter Hansen, som forenede støberiet med okse- og hestehandel. Disse to mu nedrevne gavlhuse er typiske for bebyggelsen omkring dr 1500. Huset til venstre (nr. 8) ejedes omkring 1500 af Peter Partzow, prast ved Skt. Nikolai kirke. Dansk Centralbibliotek for Sydslesvig.

$22 \frac{1}{2} \mathrm{mk}$ lybsk. Detailprisen var åbenbart lidt dyrere end det større parti. En terling Leidisk klæde med 40 stykker ville følgelig kunne indbringe ca. 850 mk. lybsk i stk.-pris og ca. $900 \mathrm{mk}$. lybsk i alenpris. ${ }^{2}$ Hvis de 2 korsbånd klæde, som Merten Risenberg i 1498 fortoldede, holdt terlingmål og indeholdt Leidisk klæde, kunne de altså så rigeligt indbringe en værdi ved salg i hertugdømmerne, der lå fuldt på højde - og lidt til - med værdien af hans udførsel af okser pågaldende år.

Da hverken pakkestørrelse eller klædesort er angivet i regnskaberne, bliver de anførte overvejelser naturligvis kun gisninger; men der er dog en del, der taler for, at de opførte klædeemballager har repræsenteret ganske betragtelige værdier. At Merten Risenberg i 1494 for et stykke Leidisk klæde på ca. $2 \times 13$ meter i hertugdømmerne fik, hvad der svarede til værdien af 7 okser, står jo i alt fald fast og er måske nok en overvejelse værd.

Selv om vi mangler egnede hollandske priseksempler, der tillader fortjenesteberegninger, tør man sandsynligvis roligt antage, at avancerne i klædehandelen var store og eftertragtede. De flensborgske oksehandlere fandt derved vej til den mest købedygtige kundekreds, fyrste, kirke og adel, der tidligere havde været forbeholdt de hanseatiske klædekøbmænd, der tilhørte et helt andet 
socialt lag $\mathrm{i}$ deres hjemby end de knockenhauere og prangere, der foretog okseopkøbet på de jyske efterårsmarkeder.

Det gav de flensborgske heste- og okseprangere helt specielle muligheder for social opstigning dels gennem øgede flokstørrelser og navnlig gennem indpas $\mathrm{i}$ det egentlige købmandsaristokrati og for de største endda til at nå helt til tops. At Merten Risenberg og Jeppe Teglgårds hustru fandt optagelse i det fornemme Kalentegilde uden først at være optaget $i$ købmandsgildet viser den helt specielle situation.

Denne udvikling var $i$ gang allerede før 1485 , hvilket ses af specielt Jeppe Teglgårds og Merten Risenbergs store heste- og okseflokke især om foråret med returfragt i klæde i det ældste Gottorpregnskab. Bag den ligger Lybæks og hansebyernes forsøg på at hindre udbredelsen af det hollandske klæde i Norden og Østersølandene, hvor de tyske købmænd følte disse klædesorter som konkurrence til den hanseatiske forhandling af de flanderske og brabantiske klædesorter. Netop i de sidste tre årtier af 15 . århundrede var denne konkurrence meget skarp.

Heri lå sikkert forklaringen på, at oksehandelen i løbet af 1480'erne og navnlig 1490'erne fik større interesse også for den egentlige købmandsstand $i$ Flensborg, som ad denne vej fandt indpas i klædeafsætningen i konkurrence med hansekøbmændene. Det gav øgede indtjeningsmuligheder og større anseelse, og omsider banede oksehandlerne sig vej til rådmandsstillingerne i løbet af 1490'erne: Markvard Holste, Merten Risenberg, Nisse Smit og i 1500 Herman Vinberg.

\section{NOTER}

1. Om kvægbruget i senmiddelalderens landbrug kan ses Poul Enemark: Oksehandelens historie ca. 1300-1700 (særtryk af: Sortbroget Kvæg - baggrund og udvikling i Danmark. Red. Aksel Pedersen, Poul Enemark, E.J.Ipsen, Vagn Broe, 1983) s. 13-16.

2. A.v. Brandt: Die Lübecker Knochenhaueraufstände 1380/84 und ihre Voraussetzungen. Studien zur Sozialgeschichte Lübecks in der 2. Hälfte des 14. Jahrhunderts (Zeitschrift des Vereins für Lübeckische Geschichte und Altertumskunde 391959 s. 123-202).

3. Enemark anf. arb. 1983 s. 19f, samme: Skinnhandel (Kulturhistorisk Leksikon for Nordisk Middelalder (cit. KLNM) XV sp. 525-29.

4. H.V.Gregersen: Studedrift og toldopkrævning i middelalderen langs den sønderjyske Hærvej (SJy årb 1973 s. 5-13).

5. Danmarks gamle Købstadlovgivning. Udg. E. Kroman (cit. DGK) I 1951. Haderslev 1455 7/9 s. 277 , jfr. $14609 / 6$ s. $279 f$.

6. Urkundenbuch der Stadt Lübeck (cit. LUB) VIII Lübeck 1889, nr. 560, 617, IX nr. 87, 209, 774) jfr. Enemark: Øksnehandel (KLNM XX sp. 675f), samme 1983 s. $21 \mathrm{f}$.

7. LUB X nr. 652.

8. Hansisches Urkundenbuch X-XI. Bearb. v. W.Stein. Leipzig 1907-1916. (cit. HUB) X nr. 435, s. 596 note $1, \mathrm{XI}$ nr. 305, s. 222 note 3. 
9. DGK II Kolding 1454 18/12 s. 117f: siden der henvises til et tilsvarende marked i Ribe, må man antage, at det fælles er et efterårsmarked for okser og forbilledet altså Ribe marked Vor Frue fødselsdag 8/9. - Handelsforordningen 1475 se DGK III København 1475 30/9 s. 106f, jfr. 1477 27/8 s. $108 f$ (også i Aarsberetninger fra det kgl. Geheimearchiv V 1871-75 s. 71). Om Ribe- og Koldingmarkeder se Enemark 1983 s. 23f.

10. I Dronning Christines Hofholdningsregnskaber. Udg. Will. Christensen 1904 (cit. Hofh) er trykt toldregnskaber fra Ribe og Kolding markeder 1504-07 (s. 163-185) og uddrag fra 1520 (s. 416f), men utrykte regnskaber fra Ribe og Kolding markeder er overleveret tillige fra 1501-03, 15081511 og 1519-21 og findes i Rigsarkivet: Registratur 108A. Specifikation af pakkernes indhold se P. Enemark: Studier i toldregnskabsmateriale i beg. af 16 . århundrede. Arrhus 1971 II s. $57 f$. Er kildebestemt i Studier I s. 25-49.

11. Gottorpsk Toldregnskab 1484-85. Udg. C.E.Andersen (Danske Magazin 6. rk. VI 1933 s. 329 376).

12. Findes i Rigsarkivet i Hertug Frederiks Arkiv. Toldregnskaber 1490-1519 (specifikation Enemark a.a. 1971 II s. 60). Anvendt af Lothar Schwetlik: Der hansisch-dänische Landhandel und seine Träger 1484-1519 (Zeitschrift der Gesellschaft für Schleswig-Holsteinische Geschichte 85/86 1961 s. 61-130, 881963 s. 93-174). Gottorpregnskabernes praksis i regnskabsførelse, sprog, skriveform, navneterminologi m.v. er undersegt af Enemark: Studier - 1971 passim.

13. Fortrinsvis H.C.P.Sejdelin: Diplomatarium Flensborgense (cit. DF) I-II Kjøbenhavn 1865-73.

14. Det vil føre for vidt at sidehenvise de enkelte toldposter i regnskaberne. Men den nære overensstemmelse mellem posterne i Ribe marked og Gottorpregnskaberne kan f.eks. ses hos Enemark 1971 II bilag 1-2 s. 199 for 1508 og 1501. Tilsvarende sammenligninger er foretaget for alle år i Ribe og Kolding, hvor muligheden foreligger.

15. DGK II Kolding 1491 1/11 s. 124. Forordningen lovfæster åbenbart blot en allerede indtrådt praksis, siden dateringen $i$ oktober (altså før forordningen) klart viser koncentrationen 8.-13. okt. i modsatning til 1485-regnskabet.

16. Enemark 1971 I s. 215-17, samme 1983 s. 28-30, samme: Øksnehandel (KLNM XX sp. 679).

17. Om forårsdrivningen se Enemark: Øksnehandel (KLNM XX så. 679f, samme 1983 s. 25-30, 3840.

18. Quellen zur Geschichte des Kölner Handels u. Verkehrs im Mittelalter, hrsg. B.Kuske, Bonn 1918-34, II nr. 1290, jfr. Enemark i KLNM XX sp. 678.

19. Flensborgernes oksehandel er tidligere kortfattet behandlet af L. Schwetlik a.a. 881963 s. 140153, Enemark 1983 s. 40, Bjørn Poulsen: Land-By-Marked. To gkonomiske landskaber i 1400tallets Slesvig. Flensborg 1988 især s. 146, 158-166, bilag 1 (s. 223-25).

19a.Beløb, der indsamledes $i$ forbindelse med en kirkefest, $i$ dette tilfælde til are for Jomfru Maria (se KLNM II sp. 581, IV sp. 241-42). Beløbet indgik i kirkens formuefond og kunne senere udlånes mod forrentning (se DF I nr. 179, II nr. 437).

20. DF I s. 90,647 , jfr. om N.T. s. 250.

21. DF I s. 72, 393. Om de flensborgske gilder se Johanne Skovgaard i Flensborg Bys Historie I 1953 s. $63-85$, isar s. $74-77$.

22. J.P.Trap: Hertugdømmet Slesvig I 1864/1975 s. 208.

23. DF I s. 249.

24. DF I s. 72 , jfr. 69,396 .

25. DF I s. 72 jfr. $69,90,393$.

26. DF I s. 249, 433, 441, J.P. Trap: Danmark 5. udg. 1966 X,2 s. 694 f.

27. DF I s. 248, 394, Repertorium Diplomaticum Regni Danici Mediævalis (cit. Rep.) II Ser. Udg. Will. Christensen nr. 8269: 1496 20/12 omtales P.A.s arvinger i Flensborg, der havde del i pant i et stenhus i Ribe, jfr. også Bjørn Poulsen a.a. 1988 s. 159.

28. DF I s. $245-46,427,439,694$.

29. DF I s. 245, jfr. 239, 249.

30. DF I s. 248.

31. DF I s. 248,394 , jfr. s. 62,70 . Om slægtskabet med Finkeslægten se DF II s. 463, jfr. 73, Knud 
Gether: Middelalder-familier i Flensborg og Nordfrisland og deres efterkommere i Danmark, Tyskland og Norge 1986/87 I s. 425.

32. DF I s. 249 , L.E.: s. 385,662 , J.C.: s. 394f. Om Lassen/Laurensen se Enemark 1971 I s. 228 f.

33. DF I s. 249 , jfr. $245 f$.

34. DF I s. 70, 250f, Bjørn Poulsen 1988 s. $142 \mathrm{f} \mathrm{m}$. henvisning i note $11 \mathrm{og} 12$, K. Gether a.a. 1986/ 87 I s. 75f, Tavle B. - En fuldstæendig fortegnelse over Flensborgs oksehandlere i Gottorp 1485 kan ses hos B.Poulsen 1988 s. 146 , dog er to af Jeppe Teglgårds poster $(54+143)$ overset, medens jeg til gengald ikke kan finde Jesse Lutkesens anførte oksepost. De øvrige afvigelser er ubetydelige.

35. DF I s. $250,394,438$, jfr. Gether $1986 / 87$ I s. 22 , 49. Foruden de angivne 3 okseposter (i alt 238) er P.D. lokaliseret til Herzogenbosch noteret $4 / 7$ for 6 heste og $15 / 9$ for 69 okser, altså samme dag som de forannavnte 80 , utvivlsomt alle fra Ribemarked.

36. L.B. er $30 / 3$ noteret fra Bredsted med 84 okser, 14/9 fra Flensborg med 60 okser og 1 hest og $5 / 4$ uden lokalisering med 162 okser. Det er helt givet samme person, men det kan blive en smags sag, hvor man vil placere okserne mængdemæssigt, ligesom P.D.s foregående post. Derfor kan et pracist okseantal vanskeligt opregnes for Flensborg 1491.

37. DF I s. 253,395 , jfr. s. 70,73 . M.H.s ægteskab m. T.W. se Gether I $1986 / 87$ s. 313 f. N.S. fortoldede allerede i 1485 en hest i Gottorp.

38. DF I s. 95, 126, 247, 392, 403, 694.

39. DF I s. $75,78,251,394$, jfr. Gether 1986/87 I s. 184, 314, Tavle 38.

40. DF I s. 99,250 f, 423.

41. DF I s. 250.

42. Schwetlik a.a. 881963 s. $137-140$.

43. DF I s. $249-50$ (H.H. \& U.H.), 396 (T.L.).

44. Om disse tyske opkøbere se Enemark 1983 s. 35-36.

45. DF I s. 252, II s. 931, jfr. tillige Danske Middelalderlige Regnskaber I: 1. Udg. G. Galster. 1953 (cit. DMR I: 1) s. 466, Danmarks Gilde- og Lavsskraaer fra Middelalderen. Udg. C. Nyrop I 1895 s. 680 , B.Poulsen 1988 s. 160 , Schwetlik 881963 s. 151 ff.

46. DF I s. 72 , memoriepenge: 649,654 f (jr. Il s. $24 f, 317,319$ ), stadsprotokol: $488-90$, St. Gertruds kapel: 675 , grundejendom: $99,428,676$, Nicolaigilde: 532 , rådmand: 712 .

47. DF II s. 925-32, 943 (galt dateret: ikke 1514, men 1495 se DMR I:1 s. 419), jfr. DMR I: 1 s. $360,413,419,427,433,470,485 f f, 507$, Schwetlik 881963 s. 147-149. Toldregnskaber fra Husum i årene omkr. 1500 findes i Rigsarkivet i Hertug Frederiks Arkiv: Toldregnskaber 1490-1519 (registrering se Enemark 1971 II s. 60), jfr. i ovrigt B. Poulsen 1988 s. 226.

48. DF I s. 421, 434 (ffr. Gether 1986/87 I s. 22), 343, 711, 719, 740, II s. 7-8, DMR I: 1 s. 419, jfr. Schwetlik 881963 s. $140-144$, B.Poulsen s. 151.

49. DF I s. 70, 719. Om E.G. se Hans Schultz Hansen: Godsejeren på tinge. Solvig gods i senmiddelalderen (Kongemagt og samfund i middelalderen. Festskrift til Erik Ulsig på 60-årsdagen 13/2 1988. Red. Poul Enemark, Per Ingesmann, Jens Villiam Jensen. Arusia-Historiske skrifter VI 1988 s. 391-407).

50. DF I s. 253.

51. DF I s. $75,251-52$, Gether $1986 / 87$ s. 186, Tavle A (hér er B.P., der senere blev rådmand dog forvekslet med farfaderen af samme navn, der anferes 1497 gift med Dorothea NN; hvilket må være rdm). Om slægtskabet mellem B.P. og borgmester Arnd Kiessenbrugge se B.Poulsen 1988 s. 253 note 26 .

52. DF I s. $248,250-51$.

53. DF I s. $74,78,254$ f, $394,396$.

54. DF I s. $91,99,398,521$, II s. 8.

55. Lübecker Ratsurteile. hrsg. v. W.Ebel I Göttingen 1955 nr. 431 s. 787 (11/8 1497), Plöner Zollrechnungen 1506 (Landesarchiv Schleswig-Holstein. Abt. 4) Registrering se Enemark 1971 II s. 60.

56. DF I s. 95-98, 250, 392. 
57. DF I: N.F.: s. 249, 394, 521, E.B. \& H.V.: 249f. N. F.s navn kunne staves på flere måder: Fians, Figant såvel i regnskaberne som i tidens øvrige kildemateriale se Enemark 1971 I s. 299, 301, 309.

58. Om Hans V.: DF I s. 247 , jfr. nr. 221 s. $736-38$, Gether 1986/87 I s. 38, 47, Tavle Al1, jfr. om Herm. V.: Gether s. 47f, om Katrine: Gether s. 184.

59. L. V.: DF I s. 91, 254, jfr. Gether 1986/87 I s. 183f, Nicolaigildet: DF I s. 516, Gether I s. 47.

60. DF I s. 251. Jens Ludiksen må ikke forveksles med heste- og klædehandleren Jesse Ludiksen, der træffes jævnligt i Gottorp 1485, og som blev medlem af købmandsgildet 1459 (DF I s. 244), og hvis søn Peter Jensen blev medlem 1495 (s. 251).

61. Om forveksling af Nisse/Niels med Claus se Enemark 1971 I s. 233f. DF I s. 250: N.T., II s. 17: C.T., jfr. Claus T. også i da. regnskaber f.eks. Hofh. s. 177.

62. C.E.G.: DF I s. 250 , jfr. tillige nr. 186, 188 (s. 662, 664f) om hans nye ægteskab med Kathrine Klekamp, og s. 720 (lavsoldermand). - Om P.H.K. se B.Poulsen 1988 s. 128, 137f, 164 og især i Skalk nr. 51986 s. 26-29.

63. DF I: F.O.: s. 396, 654, E.L.: 435, 676, H.S.: 421, 425, 651 .

64. Om Deventers og Zwolles store kvægmarkeder se Z.W.Sneller: Deventer die Stadt der Jahrmärkte, Weimar $1936 \mathrm{~s}$. 116, $119 \mathrm{f}$.

65. Om klædeemballager som returfragt for heste og okser se Enemark 1971 I s. 164f, 167-69.

66. DF II s. 926, 929, DMR I: 1 s. 360, Enemark: Klede (KLNM VIII sp. 460).

67. DMR I: 1 s. $528 f, 546,689$ f, jfr. Enemark 1971 I s. 180 f.

68. DMR I: 1 s. 434 , jfr. DF I nr. 194 , s. $684 f$.

69. DMR I: 1 s. 413, 479, Hanserecesse III (1477-1530) Bearb. v. D. Schäfer. 4 Leipzig $1890 \mathrm{nr} .429$ $\S 38-40,45$ (s. 583 m. noter) jfr. Enemark 1971 I s. 177-180.

70. DF I nr. 208 (s. 708-11), nr. 209 (s. 718-19), nr. 212 (s. 723-24).

71. Om klædeemballagerne se Enemark 1971 I s. 156-163, jfr. s. 166-167.

72. DF II s. 926, 929. Jfr. Fr. Bruns: Die Lübeckischen Pfundzollbücher von 1492-1496 (Hansische Geschichtsblätter 1908) s. 399: lakenpriser for Leidisk på $18 \mathrm{mk}$. lyb., en enkelt pakke: $15 \mathrm{mk}$. lyb., så de lybske priser lå antagelig lidt under priserne i hertugdømmerne. 